\title{
Root metaxylem and root architecture phenotypes interact to regulate water use under drought stress
}

\author{
Christopher Strock ${ }^{1}$, James Burridge ${ }^{1}$, Miranda Niemiec ${ }^{1}$, Kathleen M. Brown ${ }^{1}$, and \\ Jonathan P. Lynch ${ }^{1}$ \\ ${ }^{1}$ The Pennsylvania State University
}

May 6, 2020

\begin{abstract}
Abstract: At the genus and species level, variation in root anatomy and architecture may interact to affect strategies of drought avoidance. To investigate this idea, root anatomy and architecture of the drought-sensitive common bean (Phaseolus vulgaris) and drought-adapted tepary bean (Phaseolus acutifolius) were analyzed in relation to water use under terminal drought. Intraspecific variation for metaxylem anatomy and axial conductance was found in the roots of both species. Genotypes with high-conductance root metaxylem phenotypes acquired and transpired more water per unit leaf area, shoot mass, and root mass than genotypes with low-conductance metaxylem phenotypes. Interspecific variation in root architecture and root depth was observed where P. acutifolius has a deeper distribution of root length than P. vulgaris. In the deeper-rooted P. acutifolius, genotypes with high root conductance were better able to exploit deep soil water than genotypes with low root axial conductance. Contrastingly, in the shallower-rooted P. vulgaris, genotypes with low root axial conductance had improved water status through conservation of soil moisture for sustained water capture later in the season. These results indicate that metaxylem morphology interacts with root system depth to determine a strategy of drought avoidance and illustrate synergism among architectural and anatomical phenotypes for root function.
\end{abstract}

Title: Root metaxylem and architecture phenotypes integrate to regulate water use under drought stress

Authors: Christopher F. Strock ${ }^{1}\left(\operatorname{cfs}_{149} @ p s u . e d u\right)$

James D. Burridge ${ }^{1,2}$ (jimmy.burridge@ird.fr) Miranda D. Niemiec ${ }^{1}$ (mdn22@psu.edu) Kathleen M. Brown ${ }^{1}$ (kbe@psu.edu) Jonathan P. Lynch ${ }^{1 *}$ (jpl4@psu.edu)

Institutional Address: ${ }^{1}$ Department of Plant Science, The Pennsylvania State University, University Park, Pennsylvania 16802 USA; ${ }^{2}$ Institute de Recherche pour le Dèveloppment (IRD) UMR DIADE (IRD/Universitè de Montpellier), 911 Avenue Agropolis, 34394 Montpellier Cedex 5, France

*Corresponding Author: Jonathan P. Lynch, Email: jpl4@psu.edu, Tel.: +1 8148632256

Funding: This project was supported by the USAID Feed the Future Innovation Laboratory for Climate Resilient Beans, the Howard G. Buffett Foundation, and the National Institute of Food and Agriculture, U.S. Department of Agriculture, Hatch project 4732

Abstract: At the genus and species level, variation in root anatomy and architecture may interact to affect
strategies of drought avoidance. To investigate this idea, root anatomy and architecture of the drought-
sensitive common bean (Phaseolus vulgaris) and drought-adapted tepary bean (Phaseolus acutifolius) were
analyzed in relation to water use under terminal drought. Intraspecific variation for metaxylem anatomy and
axial conductance was found in the roots of both species. Genotypes with high-conductance root metaxylem
phenotypes acquired and transpired more water per unit leaf area, shoot mass, and root mass than genotypes
with low-conductance metaxylem phenotypes. Interspecific variation in root architecture and root depth was 
observed where $P$. acutifolius has a deeper distribution of root length than $P$. vulgaris . In the deeperrooted $P$. acutifolius,genotypes with high root conductance were better able to exploit deep soil water than genotypes with low root axial conductance. Contrastingly, in the shallower-rooted $P$. vulgaris, genotypes with low root axial conductance had improved water status through conservation of soil moisture for sustained water capture later in the season. These results indicate that metaxylem morphology interacts with root system depth to determine a strategy of drought avoidance and illustrate synergism among architectural and anatomical phenotypes for root function.

Keywords: Drought, Plant Hydraulics, Phenotyping, Phene Synergism, Root Anatomy, Root Architecture, Secondary Growth, Xylem

Acknowledgements: We thank Timothy Porch for oversight of the PR field site, Bob Snyder for oversight of lab and field activities in AZ and PA, and Meredith Hanlon, Hannah Schneider, Stephanie Klein, Jenna Reeger, and for helpful discussions.

Summary Statement: Genetic variation in metaxylem vessel phenotypes in Phaseolus species interacts with root architecture to regulate water use strategies.

Authorship Contributions: C. S. performed the experiments, analyzed the data, and wrote the article with contributions from all the authors; J. B. aided in conducting the experiments, collecting data, and contributed to the writing; M. N. helped with in silico modeling and writing; K.B. contributed to data analysis and writing, J. L. conceived and designed the study, supervised its execution, assisted with data analysis, and contributed to the writing.

\section{Introduction}

Although superior plant performance under water limitation is broadly characterized as "drought tolerance", this term obscures distinct strategies that may exist at the genus or species level for plants to cope with water deficit. Multiple combinations of root and shoot phenotypes may benefit performance under water stress through either conservation of soil water or by providing access to available water as drought progresses (Vadez, 2014). Elucidating idiosyncratic strategies of drought avoidance not only requires investigation of individual root and shoot phenotypes, but also the broader interactions between these phenes that affect water acquisition, transport, and utilization (Strocket al., 2019a). Since roots are directly responsible for water capture, investigation of the effects of interactions between anatomical and architectural root phenotypes on drought avoidance is especially relevant to both basic and applied plant biology.

While water transport through the plant is driven by transpiration and primarily regulated by stomata, within the soil $>$ plant $>$ atmosphere continuum, roots represent the greatest resistance (Purushothaman et al ., 2013; Vadez, 2014). Anatomical phenes have significant influence over the rate at which roots can transport water radially into the stele and axially to the shoots (Leitner et al ., 2014; Lynch et al . 2014). As dicotyledonous roots mature and secondary growth progresses, root tissue becomes more heavily lignified and suberized, and radial transport of water across the root is minimized (Guo et al ., 2008; Rewaldet al ., 2011; Ranathunge \& Schreiber, 2011). This process of secondary growth effectively shifts the physiological role of the roots from one of resource capture to axial transport (Steudle, 2000; Strocket al ., 2018, 2020).

Axial water transport is augmented during secondary growth through the production of secondary metaxylem elements, with the efficiency of axial conductance increasing with vessel diameter (Hacke et al., 2017; Strock et al. , 2018, 2020; Tyree et al ., 1994; Zimmerman, 1983). Although increasing rates of water and nutrient transport are necessary to support shoot growth, under situations of terminal drought, roots with narrow vessels may be advantageous in moderating desiccation of root tips and the surrounding rhizosphere for sustained soil exploration and water capture later in the season (Lynch et al ., 2014; Richards \& Passioura, 1989; Vadez, 2014). Narrow vessels may also benefit roots in drier soils where negative tension on metaxylem vessels can be severe, leaving large diameter vessels more vulnerable than narrow vessels to dysfunction through cavitation (Tyree et al ., 1994). In perennial tree and shrub species, this hydraulic failure typically occurs in the roots, where metaxylem vessels are wider and longer than vessels in the shoots (Hacke \& Sperry, 
2001; Nobel \& Jordan, 1983; Pockman \& Sperry, 2000; Sperry \& Ikeda, 1997; Sperry \& Saliendra, 1994).

Although the relationship between water use and metaxylem vessel morphology is not a novel topic, the bulk of relevant literature has been conducted with perennial tree species and monocotyledonous species (Alder et al ., 1996; Passioura, 1972; Richards \& Passioura, 1989; Sperry \& Saliendra, 1994). While the principles of water transport through the xylem apply to all vascular plants, differences in metaxylem vessel morphology and their relationship with strategies to mitigate water stress may vary significantly among species. In contrast with annual dicots, monocots lack secondary growth and seasonal development of vasculature, while perennial species are subject to different constraints and opportunities with regards to water acquisition and use (Lynch, 2019; Strock \& Lynch, 2020). Research addressing vascular development during secondary growth and intraspecific variation for metaxylem vessel morphology in annual dicots is lacking, but is essential for understanding the capacity and control of hydraulic conductance in these species (Comas et al ., 2013; Hacke et al ., 2017, Strock \& Lynch, 2020).

While axial transport of water is affected by metaxylem morphology, acquisition of water is dependent upon the spatiotemporal distribution of roots throughout the soil profile (Lynch, 2013). Root length distribution in the soil is modified by root architectural phenes such as the gravitropism of axial roots (Ho et al ., 2005; Miguelet al ., 2015; Miller et al ., 2003) as well as the elongation and abundance of lateral and axial root classes (Jia et al ., 2018; Miguel et al ., 2013; Postma et al ., 2014; Rangarajan et al ., 2018; Zhan et al ., 2015). Though root architecture and metaxylem morphology have distinct effects on water acquisition and transport, plant water relations are more broadly conceptualized through consideration of the interaction between anatomical and architectural phenotypes. For example, it is possible that in situations where deeper root architecture permits access to ample water at depth, large diameter metaxylem vessels might be more advantageous than small diameter vessels. It may also be the case that when water availability is limited, rapid water extraction can exhaust soil water reserves before the plant reaches reproductive maturity (Manschadi et al ., 2006; Palta et al ., 2011).

In this study, we explore the interaction between root metaxylem vessel morphology and root architecture on water use under terminal drought in two annual dicot species through functional-structural modeling and empirical observations of plants grown in controlled environment mesocosms and in the field. Our goals were to test the hypotheses that in annual dicots 1) there is inter- and intraspecific genetic variation for axial root metaxylem vessel morphology, 2) this variation in metaxylem vessel morphology affects water use under terminal drought stress, and 3) metaxylem vessel morphology interacts with root architecture and water availability to affect plant water status under drought stress.

To test these hypotheses, common bean (Phaseolus vulgaris L. ) and tepary bean (Phaseolus acutifolius ) were employed. These two taxa are closely related and are phenotypically similar, but are endemic to regions with disparate water availability. $P$. vulgarisevolved in mid-latitude neo-tropics of the Western hemisphere and is not well adapted to water stress (Beebe, 2014). P. acutifolius is native to the arid, rain-shadow valley of Mexico and the southwestern United States and maintains superior water status under drought compared to $P$. vulgaris, although the physiological mechanisms underlying this adaptation to water deficit are poorly understood (CIAT, 1987; Micheletto et al ., 2007; Pratt \& Nabhan, 1988; Rao et al ., 2013).

\section{Materials and Methods}

\section{Germplasm Selection}

To examine the anatomical variation present within these species, $P$. vulgaris accessions from the Andean gene pool were grown at the Apache Root Biology Center, Cochise County, Arizona, USA $\left(32.033896^{\circ} \mathrm{N}\right.$, $-109.692821^{\circ} \mathrm{W}$ ) from May through September 2015 and 2016. P. acutifolius accessions were also grown at this location from May through September 2015 and under water stress at the University of Puerto Rico Agricultural Experimental Station, Juana Diaz, Puerto Rico (18.031277 $\left.{ }^{\circ} \mathrm{N},-66.529612^{\circ} \mathrm{W}\right)$ from December through January 2016. Seeds for these studies were obtained from The International Center for Tropical Agriculture (CIAT) and the United States Department of Agriculture (USDA-ARS). At flowering, root crowns were extracted and washed, and the anatomy was analyzed from a segment of taproot $2.5 \mathrm{~cm}$ from 
the hypocotyl. Of all the axial root classes in Phaseolus species, the taproot is considered to be most important for water capture. These segments were preserved, sectioned, imaged, and analyzed with laser ablation tomography (LAT) as described in Strock et al ., (2019b) and Hall et al ., (2019). Six accessions from each species were selected for use in subsequent greenhouse and field studies. These accessions has similar taproot diameter, but distinct metaxylem vessel morphology and contrasting theoretical axial conductance across multiple environments and seasons (Figs. S1, S2). The six P. vulgaris genotypes included "Jesca", "G1368", and "PR1146-123", which were classified as having roots with a low axial conductance metaxylem phenotype ("low-conductance"), and "Blush", "VA-19", and "PI 307808", which were classified as having roots with a high axial conductance metaxylem phenotype ("high-conductance") (Figs. S1, S2). Among $P$. acutifolius genotypes "G40009", "G40010", and "G40158A" were classified as having roots with a low axial conductance metaxylem phenotype ("low-conductance"), while "G40028", "G40128", and "G40157" were classified as having roots with high axial conductance metaxylem phenotype ("high-conductance") (Figs. $\mathrm{S} 1, \mathrm{~S} 2)$.

\section{Effect of Root Anatomy on Water Use: Greenhouse Study}

This study was conducted in a greenhouse located at The Pennsylvania State University, University Park, Pennsylvania, USA $\left(40.801955^{\circ} \mathrm{N},-77.862544^{\circ} \mathrm{W}\right)$. Plants were grown from June through July 2018 under a 16:8 (light:dark) photoperiod and $\max / \min$ temperature of $28^{\circ} \mathrm{C} / 25^{\circ} \mathrm{C}$. Mid-day photosynthetic active radiation (PAR) was approximately 900-1000 $\mu \mathrm{mol}$ photons $\mathrm{m}^{-2} \mathrm{~s}^{-1}$. Natural light was supplemented from 0600 to $2200 \mathrm{~h}$ with $110 \mu \mathrm{mol}$ photons $\mathrm{m}^{-2} \mathrm{~s}^{-1}$ from LED Illumitex ES2 lights (Illumitex, Inc., Austin, TX, USA). Seeds were sterilized in a $25 \% \mathrm{NaOCl}$ solution and germinated for $24 \mathrm{~h}$ in the dark at $28^{\circ} \mathrm{C}$. Uniform seedlings were transplanted to the greenhouse in opaque, $20 \mathrm{~L}$ mesocosms $30 \mathrm{~cm}$ in diameter and $44 \mathrm{~cm}$ in height. Mesocosms were filled with a mixture of $60 \%$ medium grade sand (Quikrete Co, Inc., Atlanta, GA, USA), 20\% field soil (Ap2 Hagerstown silt loam (fine, mixed, semi-active, mesic Typic Hapludalf)) sieved through 6mm mesh, and 20\% D3 coarse grade A vermiculite (Whittemore Co., Inc., Lawrence, MA, USA). Mesocosms were fertilized with $2.5 \mathrm{~g} \mathrm{~L}^{-1}$ Osmocote (15-9-12; 3-4 mo.) (The Scotts Co., Marysville, OH, USA) incorporated into the media at the time of mixing.

A Complete Randomized Block Design was utilized with two irrigation levels; water stress (WS) and wellwatered (WW). Irrigation was supplied through drip rings, with pots being brought to field capacity daily. Irrigation was halted on pots assigned to the WS treatment at 14 days after planting (DAP). The experiment was run for a total of 42 days with destructive measurements taken from all genotypes in all treatments at 14, 28, and 42 DAP. Each genotype had three replications at each time point and treatment.

Gas exchange measurements were taken on every plant in both irrigation treatments every other hour from 09:00 to 18:00 at 13, 27, and 41 DAP using the Li-Cor LI-6400 portable photosynthesis system (Li-Cor, Lincoln, NE, USA). Gas exchange measurements were taken on young, fully expanded leaves using a PAR intensity of $1,500 \mu \mathrm{mol}$ photons $\mathrm{m}^{-2} \mathrm{~s}^{-1}$, baseline sample chamber and reference chamber $\mathrm{CO}_{2}$ concentration of $400 \mu \mathrm{mol} \mathrm{mol}{ }^{-1}$, and $40 \%$ relative humidity. At 14, 28, and 42 DAP destructive shoot measurements were taken including leaf number, leaf area, and dry shoot biomass. Leaf area was determined using the Li-Cor LI-3100C leaf area meter (Li-Cor, Lincoln, NE, USA). Dry mass was determined from tissues dried at $65^{\circ} \mathrm{C}$ for $7 \mathrm{~d}$. The root system of each plant was extracted and washed, and root architecture was measured as in Burridge et al . (2017). A $5 \mathrm{~cm}$ segment of taproot was taken immediately below the hypocotyl for anatomical analysis. The remaining root system was dried at $65^{\circ} \mathrm{C}$ for $7 \mathrm{~d}$, and the dry mass was determined.

To determine the validity of hydraulic conductance estimates calculated from transverse cross-sectional images, in situ measures of axial conductance were performed on the $5 \mathrm{~cm}$ segments of taproot in a method modified from Jacobsen (2011) and Sperry et al . (1988). Prior to measurement, each $5 \mathrm{~cm}$ root segment was soaked in a de-gassed $20 \mathrm{mM} \mathrm{KCl}$ solution for $30 \mathrm{~min}$ and lateral roots were removed with scissors. Paraffin wax was melted and painted on the surface of the root to preclude radial losses of flow through lateral root junctions across the segment. A $0.0065 \mathrm{Mpa}$ hydraulic head of degassed $20 \mathrm{mM} \mathrm{KCl}$ solution was attached to one end of the root segment and flow out the opposite end of the segment was quantified over a 5 min period using an Adventurer Pro AV13C analytical balance (Ohaus Corporation, Pine Brook, NJ USA). 
Following these in situ conductance measurements, the wax coating was removed and the root segment was preserved, sectioned at each end, and anatomical features were characterized following the protocol described above. The mean of the theoretical conductance estimate from both ends of a given segment were used for comparison with the in situ measure of conductance across that segment.

\section{Interspecific Differences in Root Depth and Water Acquisition:}

Greenhouse Study

A second greenhouse study was conducted to directly compare the root length distribution and water acquisition by depth of $P$. vulgarisand $P$. acutifolius. One genotype from each species (G40009 and VA-19) was grown from April through May 2019 in mesocosms $110 \mathrm{~cm}$ in height and $15 \mathrm{~cm}$ in diameter under the same environmental conditions as described for the previous greenhouse study. Mesocosms were irrigated to field capacity daily until 18 DAP, after which irrigation was withheld until destructive sampling.

At 34 DAP mesocosms were cut into $10 \mathrm{~cm}$ increments by depth from the soil surface to bottom of the container. Samples for gravimetric soil water content were collected and roots were washed and collected from each $10 \mathrm{~cm}$ segment of the mesocosm. Roots from each segment were imaged using an EPSON Perfection V700 PHOTO scanner and total root length was quantified with WinRhizo software (WinRhizo Pro; Reagent Instruments). The scanned roots were then dried at $60^{\circ} \mathrm{C}$ and weighed to determine specific root length, calculated by dividing the total root length by the total root dry weight.

\section{Effect of Root Architecture on Root System Depth: In Silico Study}

To investigate how the contrasting root architectures of $P$. acutifolius and $P$. vulgaris affect the distribution of roots by depth, simulations were conducted with OpenSimRoot, a functional-structural 3D plant model (Lynch et al. , 1997; Postmaet al., 2017). OpenSimRoot was parameterized with mean measures of the root architecture of each species in the field. Models of P. acutifolius root architecture had no adventitious roots, one whorl consisting of four basal roots, and a basal root angle of 40 degrees from the soil surface. Models of $P$. vulgaris had six adventitious roots, three whorls consisting of twelve basal roots, and a basal root angle of 35 degrees from the soil surface. All other plant properties were held constant in all simulations. Plant growth was simulated for 40 days after germination. Given its mobility with water in the soil profile, nitrate was used as a proxy for water in the model. To simulate water limited conditions, a mild nitrogen stress (106.5 kg/ha available N) was imposed and availability was stratified by soil depth. Boundaries were applied to permit root growth within a $0.6 \mathrm{~m} \times 0.6 \mathrm{~m} \times 1.5 \mathrm{~m}$ deep soil volume to emulate a soil volume similar to that within a planted row in the field. Further information on OpenSimRoot is provided by Postma et al. (2017), an overview of OpenSimRoot parameterization is available in Supplemental Data S1, and files used to generate this simulation are available at http://doi.org/10.5281/zenodo.3369218. OpenSimRoot source code is available for use athttps://gitlab.com/rootmodels/OpenSimRoot.

Evaluation of Inter- and Intraspecific Variation in the Field

This study was conducted at the Russell E. Larson Agricultural Research Farm, at Rock Springs, Pennsylvania, USA $\left(40.709746^{\circ} \mathrm{N},-77.956965^{\circ} \mathrm{W}\right)$ from June through September 2017 in a Hagerstown silt loam (fine, mixed, semi-active, mesic Typic Hapludalf). A split plot design was utilized with two irrigation levels; one 0.04 ha rain out shelter field was split into four, 0.01 ha blocks each and one 0.04 ha irrigated field split into four, 0.01 ha blocks. Plant species and genotypes were randomized within each block. Fields were fertilized to meet $P$. vulgaris requirements as determined by soil tests at the beginning of the season. Each genotype was planted in a three-row, $3 \mathrm{~m}$ long plot with $60 \mathrm{~cm}$ row spacing and $10 \mathrm{~cm}$ intra-row spacing. During periods of inadequate rainfall, irrigation was supplied to the well-watered treatment. Drought treatment was initiated at 20 DAP, after which plots experienced no rainfall or irrigation through time of yield harvest. Each genotype had four replications within each irrigation treatment. Average max/min temperatures of this site during this experiment were $27^{\circ} \mathrm{C} / 17^{\circ} \mathrm{C}$, total rainfall was $31 \mathrm{~cm}$, and average light:dark photoperiod was 14.5:9.5. Mid-day photosynthetic active radiation (PAR) was approximately 1500-2000 umol photons $\mathrm{m}^{-2} \mathrm{~s}^{-1}$. 
To limit the presence of fungal disease, seed were treated with Captan $50 \mathrm{~W}$ fungicide at a rate of $0.5 \mathrm{ml} / 100$ seeds prior to planting. Soil water status of the rain out shelter and control plots was monitored weekly at two locations per block by time domain reflectometry (TDR) probes buried at 15 and $30 \mathrm{~cm}$ depth that were calibrated to gravimetric samples (Fig. S3). Gas exchange measurements were taken as described above on 3 plants per plot in one block of the rain out shelter and one block of the control field every other hour from 09:00 to 18:00 at 65 DAP. Gas exchange measurements were taken using a PAR intensity of 1,500 $\mu \mathrm{mol}$ photons $\mathrm{m}^{-2} \mathrm{~s}^{-1}$, baseline sample chamber and reference chamber $\mathrm{CO}_{2}$ concentration of $400 \mu \mathrm{mol} \mathrm{mol}{ }^{-1}$, and $40 \%$ relative humidity. Stomatal density was determined from leaf prints taken from three representative leaves per plot as in Gitz \& Baker (2009). Leaf relative water content (RWC) was determined from 10, 2.5 $\mathrm{cm}$ discs taken at $60 \mathrm{DAP}$ as in Smart \& Bingham (1974).

At flowering (57 DAP), destructive shoot measurements were taken including leaf area and dry shoot biomass. Dry mass was determined from tissues dried at $65^{\circ} \mathrm{C}$. Leaf area was estimated by separating the leaf blades from stems and petioles on 5 representative plants per plot and comparing the net dry mass of leaf tissue to the specific leaf mass of the $2.5 \mathrm{~cm}$ leaf discs used for leaf RWC measurements.

Root architecture was measured as in Burridge et al. (2017). One soil core was taken in each plot to a depth of $60 \mathrm{~cm}, 5 \mathrm{~cm}$ from the base of representative plants toward plants from the neighboring row (Giddings Machine Co., Windsor, CO, USA). Soil cores were $5.1 \mathrm{~cm}$ in diameter and were divided into $6,10 \mathrm{~cm}$ increments, washed, and extracted roots from each segment were scanned and quantified as described above. The anatomy of 3 representative basal roots and 4 representative taproots was analyzed from the segment of root $2.5 \mathrm{~cm}$ from the hypocotyl. Following anatomical analysis, a $2.5 \mathrm{mg}$ subsample of ground taproot tissue was analyzed for $\mathrm{C}$ and $\mathrm{H}$ content using an elemental analyzer (Series II CHNS/O Analyzer 2400; PerkinElmer). At the end of the season, yield and yield components were calculated from $2 \mathrm{~m}$ of contiguous row per plot.

\section{Statistical Analysis}

All statistical analyses were performed using R 3.6.2 (R Foundation for Statistical Computing, 2016). Normality and homoscedasticity of the data were determined using the Shapiro-Wilk test and the non-constant error variance test respectively. Where data did not meet these assumptions, a box-cox or log transformation was used to normalize the data. Analysis of variance (ANOVA), Tukey honestly significant difference, and Pearson's regression analysis were performed with significant effects reported at $\alpha$ [?] 0.05 and $\alpha$ [?] 0.1 where noted.

To determine if the size or abundance of root traits scaled with shoot size under well-watered and water stress conditions, allometric relationships between root phenotypes and shoot mass were explored as in Strock et al. (2018).

Statistical analysis of OpenSimRoot output was not attempted, as performing statistical tests on modeling output results in artificially high $p$ values, regardless of effect size since differences in replicates are simply the result of random number generators within the model. Additionally, because the contrasting parameters are programmed into the model, it is known before the model is run that the null hypothesis is false (White et al., 2014).

\section{Results}

Metaxylem Morphology Determines Rate of Axial Transport

Estimates of axial conductance calculated from metaxylem vessels in cross-section images had a strong positive relationship with in situ measures of axial transport of roots at 14, 28 and 42 days after planting (DAP) (Fig. 1). Species differences in taproot axial conductance, metaxylem number, mean metaxylem size, and taproot TCSA were observed from 9 day old seedlings through flowering at 42 DAP (Figs. 2, S4). By flowering in both mesocosms and the field, taproots of $P$. acutifolius had more metaxylem vessels, greater total metaxylem area, and greater axial conductance than P. vulgaris(Figs. 2, S2, S4, S5). 
Intraspecific Differences in Root Anatomy Develop with Secondary Growth

Differences in taproot conductance and metaxylem size between high and low-conductance phenotypic groups were first statistically detectable inP. acutifolius at 28 DAP, and in P. vulgaris by 42 DAP (Fig. 2, S4). In water stressed $P$. acutifolius, high-conductance genotypes had $74 \%$ greater axial conductance and $45 \%$ larger mean metaxylem size than low-conductance $P$. acutifolius genotypes at 42 DAP (Fig. 2, S4). In water stressed $P$. vulgaris,high-conductance genotypes had $114 \%$ greater axial conductance, $56 \%$ greater total metaxylem area, and $37 \%$ larger mean metaxylem size compared to low-conductance $P$. vulgaris genotypes at 42 DAP (Fig. 2, S4). Despite these intraspecific differences in metaxylem traits and axial conductance, no phenotypic differences in taproot cross sectional area were detected between high and low-conductance groups in either species (Fig. 2, S4). Similar trends in anatomy were observed in the field (Figs. S2, S5). These intraspecific differences in metaxylem traits and axial conductance were also observed under well-watered conditions (Figs. S2, S5).

In addition to quantitative differences in metaxylem vessel phenes and conductance, roots of the three highconductance genotypes in both species had less abundant xylem parenchyma and tracheids, as well as a thin, bark-like periderm. Low-conductance genotypes displayed a greater abundance of xylem parenchyma and tracheids, as well as a thicker, corky periderm (Fig. 3). In both species, differences in chemical composition of roots was revealed through elemental analysis, which showed greater concentrations of carbon (C) and hydrogen $(\mathrm{H})$ in the roots of low-conductance genotypes compared to high-conductance genotypes (Fig. 3).

\section{Interspecific Differences Exist in Root Architecture and Allocation to Root Growth}

By 42 DAP there were no intraspecific differences in root mass, or the root mass - shoot mass ratio under either irrigation treatment (Fig. 4). However, under water stress, P. vulgaris had $150 \%$ greater root mass than $P$. acutifolius despite $P$. vulgaris having smaller shoot mass, leaf area, and leaf number than $P$. acutifolius (Figs. 4, S6). Correspondingly, P. vulgaris had greater relative, as well as actual allocation to root mass thanP. acutifolius (Fig. 4). Allometric analysis further revealed that root mass had no relationship with plant size in $P$. acutifolius (Table 1), while in $P$. vulgaris root mass had a negative relationship to shoot size under water stress and a positive relationship with shoot size under well-watered conditions (Table 2).

Interspecific Differences in Root Architecture

With regards to root architecture, in both mesocosms and the field, no consistent differences were observed between high- and low-conductance genotypes within each species. However, interspecific differences were observed where $P$. vulgaris had significantly greater basal root number, basal root whorl number, and adventitious root number than P. acutifolius (Fig. S7, S8). Additionally, in the field,P. vulgaris had a $10 \%$ shallower basal root growth angle compared to P. acutifolius (Fig.S8).

Interspecific Differences in Root Depth and Water Acquisition

In mesocosms, $P$. acutifolius had greater total root length and fine root length $(<0.12 \mathrm{~mm}$ in diameter $)$ in the deepest regions of the soil column, and greater specific root length from $10 \mathrm{~cm}$ depth to the bottom of the column compared to P. vulgaris (Fig. S9). After 16 days without irrigation, P. acutifolius had lower gravimetric water content below $70 \mathrm{~cm}$ compared to $P$. vulgaris $(\mathrm{t}=-3.38 ; \mathrm{p}=0.002)$ and gravimetric soil water content was reduced in regions of the soil column where there was greater total length of fine roots $(<0.12 \mathrm{~mm}$ in diameter) (Figs. 5, S10). In the field, P. acutifolius also had a greater depth at which $75 \%$ or root length was observed in soil cores compared to P. vulgaris (Fig. S8).

Root Architecture Determines Root Depth

Functional-structural modeling of the root length distribution of these two Phaseolus species revealed that the differences in root architectural phenotypes alone can account for species differences in root depth. A greater abundance of axial roots (basal and adventitious roots) and a shallower basal root growth angle in P. vulgariscontributed to $45-257 \%$ greater root length in shallow soil strata (0 to $60 \mathrm{~cm}$ from the soil surface) compared to P. acutifolius (Fig. 5). In contrast, less allocation to axial roots and a steeper basal 
root growth angle in P. acutifolius afforded this species $103-1498 \%$ greater root length at depths $>70 \mathrm{~cm}$ from the soil surface compared to P. vulgaris (Fig. 5).

Root Anatomical Features Do Not Consistently Scale with Plant Size

By 42 DAP in water-stressed mesocosms, no anatomical trait scaled with plant size in either species (Tables $1,2)$. Under water stress in the field, allometric analysis indicated that metaxylem traits and conductance had a hyperallometric relationship with plant size in $P$. acutifolius but still did not scale with plant size in $P$. vulgaris (Tables 1, 2).

Contrasting Effects of Metaxylem on Shoot Growth Between Species

Under water stress in mesocosms, high- and low-conductance groups within each species had comparable leaf area and shoot mass (Fig. S6). However, in the field, correlation analysis indicated that under water stress, biomass was suppressed to a greater extent in $P$. acutifoliusplants with roots that had fewer metaxylem vessels, smaller net metaxylem area, and lower axial conductance (Fig. 6). Direct comparison of high- and low-conductance groups of field-grown $P$. acutifoliusunder water stress confirmed that genotypes with high axial conductance roots had $71 \%$ greater shoot mass and $91 \%$ greater leaf area than genotypes with low axial conductance roots (Fig. S11).

In contrast to $P$. acutifolius, correlation analysis revealed that the biomass of water stressed $P$. vulgaris in the field was suppressed to a greater degree in plants with many metaxylem vessels, large net metaxylem area, and large axial conductance in their roots (Fig. 6). Despite these significant correlations, no statistically significant differences for shoot size were observed between high and low-conductance phenotypic groups within $P$. vulgaris under water stress in the field (Fig. S11).

Within its native range $\left(\sim 20-35^{\circ} \mathrm{N}\right)$ (Bitocchi et al. , 2017), P. acutifolius is capable of greater grain yield than P. vulgaris under drought (Fig. S12). However, for Phaseolus species grown at latitudes outside of their native distribution, photoperiod sensitivity can delay flowering and suppress grain yield (Fig. S13) (Kwak et al., 2008; Pratt \& Erikson, 1982; Raggi et al. , 2019; Thomas, 1983; White \& Laing, 1989). While utilizing diverse germplasm provides insight into the natural variation that exists for root architecture and anatomy in these species, local adaptation to specific latitudes and photoperiod regimes hinders the capacity to make inter- and intraspecific comparisons of grain yield within a single environment (Singh et al. , 1991). Furthermore, grain yield of Phaseolus under drought is influenced by other factors beyond water acquisition including pollen viability (Gross \& Kigel, 1994), as well as photosynthate mobilization and grain filling (Polania et al. , 2016). Consequently, among this diverse set of material grown at the Pennsylvania field site, neither intra- nor interspecific differences in yield were observed under water stress, and conductance phenotypes also had comparable yield under well-watered conditions (Fig. S13).

No Intraspecific Differences in Leaf Morphology

No differences in specific leaf mass were observed within either species, but under water stress, $P$. acutifolius genotypes had thicker leaves than P. vulgaris genotypes (Fig. S11). While stomatal density and size were also comparable between high and low-conductance phenotypes within each species, stomata were $21 \%$ and $47 \%$ larger in P. acutifolius than P. vulgaris under water stress and well-watered conditions, respectively (Fig. S14).

\section{Metaxylem Vessels in Roots Impact Water Use Under Drought}

Although species differences in the rate of transpiration were not observed at any time of day in water stressed mesocosms (Fig. 7), by 42 DAP P. acutifolius had still transpired more water than P. vulgaris under water stress (Fig. 8). Taking into account interspecific differences in the size of roots and shoots, $P$. acutifoliustranspired more water per unit root mass than $P$. vulgaris, while $P$. vulgaris transpired more water per unit shoot mass thanP. acutifolius (Fig. 8).

In mesocosms, intraspecific differences in transpiration rate were observed for both species. At 27 DAP at the onset of terminal water limitation, high-conductance genotypes in both species had greater rates of tran- 
spiration in the morning, but smaller rates of transpiration in the afternoon than low-conductance genotypes (Fig. 7). By 41 DAP, at the advanced phase of terminal water limitation, low-conductance genotypes of both species were able to maintain greater rates of transpiration throughout the entire day compared to high-conductance genotypes (Fig. 7). By 42 DAP, high-conductance genotypes in both species had greater net transpirational water loss from mesocosms, as well as greater water loss per unit leaf area, shoot mass, and root mass compared to low-conductance genotypes (Fig. 8).

\section{Metaxylem Vessels and Root Depth Interact in the Field to Affect Water Use}

At 64 DAP in the field, phenotypic differences in the rate of transpiration were only observed within $P$. vulgaris. To account for differences in plant size that may influence net water use, gas exchange rates were compounded by total leaf area. While the extrapolation of gas exchange rates by total leaf area likely overestimates net water transpired, these metrics still provide a useful perspective on water use. When gas exchange rates were compounded by leaf area, phenotypic differences were observed throughout the day within both species under water stress. At this later timepoint of terminal drought in the field where soil water availability increased with soil depth (Fig. S3), high-conductance genotypes of the deep-rooted $P$. acutifolius had greater leaf RWC and net transpiration than low-conductance genotypes (Fig. 9). In contrast, genotypes of the shallow-rooted $P$. vulgaris with high-conductance had smaller leaf RWC and net transpiration than low-conductance genotypes (Fig. 9). In water-stressed P. vulgaris, plants that maintained greater leaf RWC had smaller total metaxylem area, metaxylem number, taproot TCSA, and taproot conductance (Fig. S15).

\section{Discussion}

Observations from both mesocosms and the field highlight the interaction between metaxylem vessel morphology and root architecture on water transport and use under drought stress in annual dicots. These results confirm the hypotheses that in two contrasting Phaseolus species 1) there is inter- and intraspecific diversity for metaxylem vessel morphology (Figs. 2, S1, S2, S5), 2) this variation in metaxylem vessel morphology is related to water transport and use under terminal drought stress (Figs. 1, 7, 8, 9), and 3) metaxylem morphology integrates with root and shoot phenotypes in distinct water use strategies between these annual species (Figs. 4, 6, 9, S11).

While water availability and experimental platform had a significant effect on the scale of metaxylem features, inter- and intraspecific differences in axial conductance were consistent across all environments, indicating that these differences are not a response to extrinsic factors, but are driven by a strong genetic component (Figs. 2, 3, S1, S2, S4, S5). Comparable taproot diameters among genotypes suggest that differences in conductance and metaxylem vessel morphology were not the product of contrasting rates of secondary growth, but rather differences in patterns of tissue differentiation as secondary growth progressed (Figs. 2, 3, S1, S2, S4, S5). Genotypes with high conductance had greater production of secondary metaxylem vessels and very little xylem parenchyma, tracheids, and periderm. This anatomical phenotype may be adaptive for maximum transport efficiency in environments where water is always abundant, risk of cavitation is low, and damage to roots by disease or edaphic herbivores is minimal. Roots of the low-conductance phenotype had less allocation to secondary metaxylem vessels but more xylem parenchyma, tracheids, and periderm tissue. This anatomical phenotype may be adaptive for roots in drying soils where conservation of limited soil water, consistent transport, and protection of vasculature from air seeding, pathogens, or edaphic herbivores are essential for greater fitness. The abundance of xylem parenchyma surrounding the vessels in low-conductance roots may also provide some capacity for water storage to help buffer declines in soil water potential, as well as play a role in nocturnal refilling of cavitated vessels (Nobel \& Jordan, 1983; Stiller et al ., 2005). Numerous tracheids in the stele of low-conductance phenotypes may prevent total hydraulic failure in drier soils by providing an alternate pathway for water transport when larger vessel elements have cavitated (Calquist, 2012).

Differences in the elemental composition of high- and low-conductance roots point to differential partitioning in anatomy and cell wall structure (Fig. 3). Greater concentrations of $\mathrm{C}$ and $\mathrm{H}$ in low-conductance genotypes is likely driven by the thicker periderm of these roots, a secondary protective tissue that contains 
high concentrations of suberin, wax, and other fatty substances (Chen, 2014; Schreiber, 2010). Compared to other principal cell wall components, such as cellulose $(44 \% \mathrm{C}, 6 \% \mathrm{H})$, hemicellulose (xylose $\sim 40 \% \mathrm{C}, 7 \% \mathrm{H}$ ), pectin $(37 \% \mathrm{C}, 5 \% \mathrm{H})$, and lignin $(\sim 63 \% \mathrm{C}, 6 \% \mathrm{H})$, suberin, waxes, and lipids have proportionally greater concentrations of $\mathrm{C}$ and $\mathrm{H}$ by mass $(\sim 72 \% \mathrm{C}, 11 \% \mathrm{H})$. A thicker, suberized periderm may help to hydraulically isolate roots from drying surface horizons, preventing leakage and air seeding through interconduit pit membranes, thereby preserving the hydraulic integrity of the vasculature (Cuneo et al ., 2016; Hacke \& Sperry, 2001; Sperry \& Saliendra, 1994; Zwieniecki et al ., 2003).

When integrated across an entire root system, small genotypic differences in metaxylem vessel morphology and anatomical composition had significant effects on water transport and utilization. Variation in metaxylem vessel number and size were strongly correlated with axial transport and this in turn had significant effects on water use per unit leaf area, shoot mass, and root mass in both species (Figs. 1, 8). The absence of significant intraspecific variation in other root or shoot traits including root architecture, leaf area, stomatal size, or stomatal density in either species suggests that these differences in water use occurred at the level of water transport within the plant, rather than elicited by allometric effects of root or shoot size on water capture or transpiration rates (Tables 1,2).

In humid environments with sufficient water availability and low risk of cavitation, roots with greater conductance are generally considered adaptive in affording greater water and nutrient transport for growth (Comas et al ., 2013; Purushothaman et al ., 2013; Tyreeet al ., 1994). However, high-conductance root systems that fail to meter water transport and are susceptible to cavitation will impair plant fitness in terminal drought environments where water availability is suboptimal (Comas et al ., 2013; Lynch et al ., 2014; Vadez, 2014). This was supported by gas exchange rates in mesocosms at the onset of water stress, where high-conductance genotypes had initially greater transpiration in the morning followed by abrupt declines in the afternoon (Fig. 7). The mid-day decline in transpiration of the high-conductance genotypes probably corresponded with stomatal closure or cavitation events in the roots. As drought stress became more severe (41d), the high-conductance genotypes had significantly less leaf RWC and were almost completely impaired in gas exchange compared to low-conductance genotypes. The greater rates of gas exchange, leaf RWC, and shoot size of reduced conductance roots in mesocosms is an example of a water conservation strategy to avoid the effects of soil water deficit and improve the efficiency of water use (Lynch et al ., 2014). These results from mesocosms align with reports in other species where metaxylem vessel morphology related to a drought avoidance strategy through water conservation and resistance to cavitation that improved water use efficiency (Alder et al ., 1996; Gallardoet al ., 1996; Passioura, 1972; Richards \& Passioura, 1989; Sperry \& Saliendra, 1994; Tyree et al ., 1994).

Although the influence of metaxylem morphology on axial transport and water use was apparent, physiological traits affecting the acquisition, transport, and release of water have multifaceted interactions with one another and often have fitness tradeoffs that restrict their utility in specific environments (Lynch, 2019). While comparable intraspecific variation for metaxylem vessel morphology and conductance was present in both species, integration of these root hydraulic traits with other components of root and shoot physiology had contrasting effects on performance in P. acutifolius and P. vulgaris .

One of the principle differences between these two species was the interaction of metaxylem vessel morphology with the allocation of biomass within the root system (Fig. 4). P. acutifolius has less root mass but was still able to capture and utilize more water than P. vulgaris, demonstrating that root system size was not a limiting factor in water acquisition under drought stress (Figs. 4, 7, 8). Greater abundance and size of metaxylem vessels allows $P$. acutifolius to maintain robust transport of water and nutrients with a smaller root system compared to P. vulgaris, similar to observations in other species (Gallardo et al ., 1996; LazcanoFerrat \& Lovatt, 1999; Prince et al ., 2017). Lazcano-Ferrat \& Lovatt (1999) also reported P. acutifolius had a smaller root system, but comparable shoot mass and greater leaf RWC than $P$. vulgaris under water stress.

Reduced root:shoot ratio has also been correlated with greater rooting depth in Phaseolus species (Berny Mier y Teran et al ., 2018) and P. acutifolius' ability to cope with a drying epipedon has been credited to the 
proliferation of roots at depth (Pratt \& Nabhan, 1988; Rao et al ., 2013; Thomas, 1983). Root system depth in Phaseolus is an aggregate of multiple root architectural phenes including gravitropism of axial roots as well as the abundance of axial roots such as basal and adventitious roots. The gravitropic response of axial roots impacts growth angle in the soil and axial root number directly affects root distribution, since basal and adventitious roots emerge at the soil surface (Bonser et al ., 1996; Miguelet al ., 2013; Miller et al ., 2003). Greater numbers of axial roots also indirectly limit root system depth by competing for photosynthate and slowing elongation of the taproot into deeper soil domains (Figs. 5, S8, S9) (Lynch, 2019). In the present study, in silico results show that root architectural phenes act as regulators of root length distribution across depth (Fig. 5). Steeper basal root growth angles and less resource allocation to axial root growth afforded $P$. acutifolius a greater proportion of root length distribution deeper in the soil profile than $P$. vulgaris (Fig. 5 , S8, S9). While a greater abundance of axial roots may limit the rooting depth of $P$. vulgaris, it increases the overall conductance of the root system of this species and may make up for the lesser conductance rates per root in terms of total water flow to the shoot. This greater total conductance of the shallow root system of $P$. vulgaris likely contributes to its superior performance under well-watered conditions compared to $P$. acutifolius (Fig. S11).

While root anatomy and architecture are independent features of the root system that have distinct roles for water acquisition and transport, the results of this work suggest that these independent components can have integrated effects on plant-water relations. The integration of metaxylem vessel morphology and root depth was highlighted in the contrasting performance of $P$. acutifolius in mesocosms and in the field. In mesocosms where root depth was restricted, high-conductance genotypes in both species had greater water transport and use, and consequently suffered from lower leaf RWC and gas exchange rates as drought stress intensified (Figs. 7, 8). In the field however, where water availability was stratified and root depth less restricted (Fig. S3), high-conductance genotypes of the deeper-rooted $P$. acutifolius had greater leaf RWC, larger biomass, and greater rates of gas exchange (Figs. 5, 9). This divergent performance between environments where root depth and water stratification were altered demonstrates the impact that interactions of multiple root phenes and environmental conditions have on the fitness landscape of a given phenotype.

The contrasting interactions between metaxylem phenotypes and rooting depth in $P$. acutifolius and $P$. vulgaris highlight the ability of root axial conductance to have either synergistic or antagonistic interactions with root depth under water limitation. The synergistic interaction between high-conductance root anatomy and deep roots in $P$. acutifolius demonstrates the utility of efficient axial transport in supporting growth when root depth provides access to water (Prince et al ., 2017). The low-conductance phenotype within this species has an antagonistic interaction with deeper roots by reducing the capacity for transport of water to the growing shoot under stress. Complementarity between the low-conductance phenotype and shallow roots in P. vulgaris reveals the utility of constraining water uptake to maintain limited soil water reserves and reduce desiccation of root tips and the rhizosphere for sustained water capture later in the season. Despite strong relationships between metaxylem vessel morphology and axial transport, no suppression of biomass was observed in reduced conductance genotypes under well-watered conditions, similar to reports in wheat by Richards and Passioura (1989). The unhampered growth of low conductance genotypes in the well-watered treatment suggests that axial transport was not a limiting component to shoot growth under these conditions.

The observed interspecific variation for both root anatomy and architecture likely reflects adaptation to the native environments of each species. P. acutifolius evolved in arid, rain-fed ecosystems where little supplemental rainfall occurs following seasonal monsoon rains that initiate germination (Pratt \& Nabhan, 1988; Rao et al., 2013). As the soil dries in these terminal drought conditions, water is distributed along a gradient in the soil profile, with availability increasing with soil depth (Manschadi et al ., 2006; Lynch, 2013; Lynch \& Wojciechowski, 2015). This gradient of matric potential can be quite extreme in this species' native range, where surface horizons are below permanent wilting point $(-1.5 \mathrm{MPa})$ while soil at $1 \mathrm{~m}$ is totally saturated (Bengough et al ., 2006). Under these conditions, a deep foraging root system with greater transport efficiency is well suited for access to deep water later in the growing season. 
In contrast, $P$. vulgaris evolved in mid-latitude neo-tropics of the Western hemisphere and has a root system that is poorly adapted to terminal drought conditions (Beebe, 2014). The shallow, well branched root system of this species is most suited to foraging for immobile nutrients like phosphorus; a primary limitation to plant growth throughout its native distribution where volcanic (Andosols) and weathered mineral soils (Oxisols, Utisols, some Alfisols) characterized by Fe and Al oxide chemistry are prevalent (Lynch \& Beebe, 1995). Although phosphorus availability is a constitutive limitation to plant growth in this region, in conditions where $P$. vulgaris may concurrently experience water limitation, the low-conductance anatomy phenotype likely affords this species some ability to meter water extraction from a drying epipedon where the bulk of its root system is distributed.

While this study highlights the integration of root metaxylem vessel morphology and root architecture for water use in Phaseolusspecies, these results have broader relevance to plant-water relations for other annual dicotyledonous species. Intraspecific variation for metaxylem vessel morphology is likely to be present in many annual dicots and further research to explore the relationship between anatomy, root architecture, and water use requires consideration of secondary growth and seasonal development of the vasculature, water availability, and water transport throughout the life cycle of the plant. The integration of root anatomy with other mechanisms for drought adaptation, such as shifts in phenology as well as allocation to sexual or vegetative growth, must also be carefully considered.

These results indicate that metaxylem morphology interacts with root system depth to determine drought avoidance in these species and illustrate the importance of synergism among architectural and anatomical phenotypes for root function. The utility of metaxylem morphology is contingent upon root architecture with respect to moisture availability. In terminal drought environments where water is available at depth, maintaining deeper root systems with greater conductance maximizes productivity of these Phaseolus species. Although root metaxylem vessel morphology is just one component of plant water relations, it can have synergistic or antagonistic interactions with other phenes to affect water acquisition and use in particular drought scenarios. The integration of multiple root and shoot phenotypes, as well as the spatiotemporal availability of water, will ultimately determine the optimal root metaxylem morphology in a given environment. These insights are relevant to the challenge of matching root phenotypes related to water use with environments in legumes and other annual dicotyledonous crops.

Acknowledgements: We thank Timothy Porch for oversight of the PR field site, Bob Snyder for oversight of lab and field activities in AZ and PA, and Meredith Hanlon, Hannah Schneider, Stephanie Klein, Jenna Reeger, and for helpful discussions.

\section{References}

Alder N.N., Sperry J.S. \& Pockman W.T. (1996). Root and stem xylem embolism, stomatal conductance, and leaf turgor in Acer grandidentatum populations along a soil moisture gradient.Oecologia, 105(3), 293-301.

Beebe S.E., Rao I.M., Devi M.J. \& Polania J. (2014). Common beans, biodiversity, and multiple stresses: challenges of drought resistance in tropical soils. Crop \& Pasture Science, 65(7), 667-675.

Bengough A.G., Bransby M.F., Hans J., McKenna S.J., Roberts T.J. \& Valentine T.A. (2006). Root responses to soil physical conditions; growth dynamics from field to cell. Journal of Experimental Botany , 57(2), 437447.

Berny Mier y Teran J.C., Konzen E.R., Medina V., Palkovic A., Ariani A., Tsai S.M., Gilbert M.E. \& Gepts P. (2018). Root and shoot variation in relation to potential intermittent drought adaptation of Mesoamerican wild common bean (Phaseolus vulgaris L.). Annals of Botany , 124(6), 917-932.

Bitocchi E., Rau D., Bellucci E., Rodriguez M., Murgia M.L., Gioia T., Santo D., Nanni L., Attene G. \& Papa R. (2017). Beans (Phaseolusssp.) as a Model for Understanding Crop Evolution. Frontiers in Plant Science, , 8, 722 .

Bonser A.M., Lynch J.P. \& Snapp S. (1996). Effect of phosphorus deficiency on growth angle of basal roots 
in Phaseolus vulgaris .New Phytologist, 132(2), 281-288.

Burridge J.D., Schneider H.M., Huynh B.L., Roberts P.A., Bucksch A. \& Lynch J.P. (2017). Genome-wide association mapping and agronomic impact of cowpea root architecture. Theoretical and Applied Genetics, 130(2), 419-431.

Carlquist S. (2012). How wood evolves: a new synthesis. Botany Botanique, 90(10), 901-940.

Chen H. (2014). Biotechnology of Lignocellulose: Theory and Practice. In Chemical composition and structure of natural lignocellulose (ed H. Chen), pp. 73-141. Chemical Industry Press, Beijing and Springer, Dordrecht.

CIAT. (1987). Annual Report. Bean Program. International Center for Tropical Agriculture. Cali, Columbia.

Comas L.H., Becker S.R., Cruz V.V., Byrne P.F. \& Dierig D.A. (2013). Root traits contributing to plant productivity under drought.Frontiers in Plant Science, 4, 16.

Cuneo I.F., Knipfer T., Brodersen C.R. \& McElrone A.J. (2016). Mechanical Failure of Fine Root Cortical Cells Initiates Plant Hydraulic Decline during Drought. Plant Physiology, 172(3), 1669-1678.

Gallardo M., Eastham J., Gregory P.J. \& Turner N.C. (1996). A comparison of plant hydraulic conductances in wheat and lupins. Journal of Experimental Botany, 47(295), 233-239.

Gitz D.C. \& Baker J.T. (2009). Methods for Creating Stomatal Impressions Directly onto Archivable Slides. Agronomy Journal, 101(1), 232-236.

Gross Y. \& Kigel J. (1994). Differential sensitivity to high temperature of stages in the reproductive development of common bean (Phaseolus vulgaris L.). Field Crops Research , 36(3), 201-212.

Guo D.L., Xia M.X., Wei X., Chang W.J., Liu Y. \& Wang Z.Q. (2008). Anatomical traits associated with absorption and mycorrhizal colonization are linked to root branch order in twenty-three Chinese temperate tree species. New Phytologist, 180(3), 673-683.

Hacke U.G. \& Sperry J.S. (2001). Functional and ecological xylem anatomy. Perspectives in Plant Ecology Evolution and Systematics, 4(2), 97-115.

Hacke U.G., Spicer R., Schreiber S.G. \& Plavcova L. (2017). An ecophysiological and developmental perspective on variation in vessel diameter. Plant Cell and Environment, 40(6), 831-845.

Hall B., Lanba A. \& Lynch J. (2019). Three-dimensional analysis of biological systems via a novel laser ablation technique. Journal of Laser Applications, 31, 1-5.

Ho M.D., Rosas J.C., Brown K.M. \& Lynch J.P. (2005). Root architectural tradeoffs for water and phosphorus acquisition. Functional Plant Biology, 32, 737-748.

Jacobsen A. (2011). Measuring the hydraulic conductivity of plant samples. 10.13140/RG.2.2.25908.35202.

Jia X., Lui P. \& Lynch J.P. (2018). Greater lateral root branching density in maize (Zea mays L.) improves phosphorus acquisition from low phosphorus soils. Journal of Experimental Botany, 69(20), 4961-4970.

Johnson D.M., Brodersen C.R., Reed M., Domec J.C. \& Jackson R.B. (2014). Contrasting hydraulic architecture and function in deep and shallow roots of tree species from a semi-arid habitat. Annals of Botany, $113(4), 617-627$.

Kwak M., Velasco D. \& Gepts P. (2008). Mapping homologous sequences for determinacy and photoperiod sensitivity in common bean (Phaseolus vulgaris ). Journal of Heredity , 99, 283-291.

Lazcano-Ferrat I. \& Lovatt C.J. (1999). Relationship between relative water content, nitrogen pools, and growth of Phaseolus vulgarisL. and P-acutifolius A. Gray during water deficit. Crop Science, 39(2), 467-475. 
Leitner D., Meunier F., Bodner G., Javaux M. \& Schnepf A. (2014). Impact of contrasted maize root traits at flowering on water stress tolerance - A simulation study. Field Crops Research, 165, 125-137.

Lynch J.P. (2013). Steep, cheap and deep: an ideotype to optimize water and N acquisition by maize root systems. Annals of Botany,112(2), 347-357.

Lynch J.P. (2019). Root phenotypes for improved nutrient capture: underexploited opportunities for global agriculture. New Phytologist, 223(2), 548-564.

Lynch J.P. \& Beebe S.E. (1995). Adaptation of beans (Phaseolus vulgaris L.) to low phosphorus availability. HortScience, 30, 1165-1171.

Lynch J.P., Chimungu J.G. \& Brown K.M. (2014). Root anatomical phenes associated with water acquisition from drying soil: targets for crop improvement. Journal of Experimental Botany, 65(21), 6155-6166.

Lynch J.P., Nielsen K.L., Davis R.D. \& Jablokow A.G. (1997). SimRoot : modelling and visualization of root systems.Plant and Soil, 188(1), 139-151.

Lynch J.P. \& Wojciechowski T. (2015). Opportunities and challenges in the subsoil: pathways to deeper rooted crops. Journal of Experimental Botany , 66(8), 2199-2210

Manschadi A.M., Christopher J., deVoil P. \& Hammer G.L. (2006). The role of root architectural traits in adaptation of wheat to water-limited environments. Functional Plant Biology, 33(9), 823-837.

Micheletto S., Rodriguez-Uribe L., Hernandez R., Richins R.D., Curry J. \& O’Connell M.A. (2007). Comparative transcript profiling in roots ofPhaseolus acutifolius and P-vulgaris under water deficit stress. Plant Science, 173(5), 510-520.

Miguel M.A., Postma J.A. \& Lynch J.P. (2015). Phene synergism between root hairs and basal root growth angle for phosphorus acquisition in common bean. Plant Physiology, 167(4), 1430-1439.

Miguel M.A., Widrig A., Vieira R.F., Brown K.M. \& Lynch J.P. (2013). Basal root whorl number: a modulator of phosphorus acquisition in common bean (Phaseolus vulgaris ). Annals of Botany, 112(6), 973-982.

Miller C.R., Ochoa I., Nielsen K.L., Beck D. \& Lynch J.P. (2003). Genetic variation for adventitious rooting in response to low phosphorus availability: potential utility for phosphorus acquisition from stratified soils. Functional Plant Biology, 30(9), 973-985.

Nobel P.S. \& Jordan P.W. (1983). Transpiration stream of desert species - resistances and capacitances for a C-3, a C-4, and a CAM plant.Journal of Experimental Botany , 34(147), 1379-1391.

Palta J.A., Chen X., Milroy S.P., Rebetzke G.J., Dreccer M.F. \& Watt M. (2011). Large root systems: are they useful in adapting wheat to dry environments? Functional Plant Biology, 38(5), 347-354.

Passioura J.B. (1972). Effect of root geometry on yield of wheat growing on stored water. Australian Journal of Agricultural Research, 23(5), 745-+.

Pena-Valdivia C.B., Sanchez-Urdaneta A.B., Rangel J.M., Munoz J.J., Garcia-Nava R. \& Velazquez R.C. (2010). Anatomical root variations in response to water deficit: wild and domesticated common bean (Phaseolus vulgaris L.). Biological Research, 43(4), 417-427.

Pockman W.T. \& Sperry J.S. (2000). Vulnerability to xylem cavitation and the distribution of Sonoran desert vegetation. American Journal of Botany , 87(9), 1287-1299.

Polania J., Rao I.M., Cajiao C., Rivera M., Raatz B. \& Beebe S. (2016). Physiological traits associated with drought resistance in Andean and Mesoamerican genotypes of common bean (Phaseolus vulgaris L.).Euphytica , 210, 17-29.

Postma J.A., Dathe A. \& Lynch J.P. (2014). The optimal lateral root branching density for maize depends on nitrogen and phosphorus availability. Plant Physiology , 166(2), 590-602. 
Postma J.A., Kuppe C., Owen M.R., Mellor N., Griffiths M., Bennett M.J., Lynch J.P. \& Watt M. (2017). OpenSimRoot : Widening the scope and application of root architectural models. New Phytologist,215(3), 1274-1286.

Pratt R.C. \& Erikson H.T. (1982). Flowering response of Phaseolus acutifolius Gray and subspecies to photoperiod. Annual Report Bean Improvement Cooperative , 25, 1-2.

Pratt R.C. \& Nabhan G.P. (1988). Evolution and Diversity of Phaseolus acutifolius Genetic Resources. In Genetic Resources of Phaseolus Beans. Current Plant Science and Biotechnology in Agriculture, vol 6 (ed P. Gepts), pp. 409-440, Springer, Dordrecht.

Prince S.J., Murphy M., Mutava R.N., Durnell L.A., Valliyodan B., Shannon J.G. \& Nguyen H.T. (2017). Root xylem plasticity to improve water use and yield in water-stressed soybean. Journal of Experimental Botany , 68(8), 2027-2036.

Purushothaman R., Zaman-Allah M., Mallikarjuna N., Pannirselvam R., Krishnamurthy L. \& Gowda C.L.L. (2013). Root Anatomical Traits and Their Possible Contribution to Drought Tolerance in Grain Legumes.Plant Production Science, 16(1), 1-8.

Raggi L., Caproni L., Carboni A. \& Negri V. (2019). Genome-Wide Association Study Reveals Candidate Genes for Flowering Time Variation in Common Bean (Phaseolus vulgaris L.). Frontiers in Plant Science, 10,962 .

Ranathunge K. \& Schreiber L. (2011). Water and solute permeabilities of Arabidopsis roots in relation to the amount and composition of aliphatic suberin. Journal of Experimental Botany, 62(6), 1961-1974.

Rangarajan H., Postma J.A. \& Lynch J.P. (2018). Co-optimisation of axial root phenotypes for nitrogen and phosphorus acquisition in common bean. Annals of Botany, 122(3), 485-499.

Rao I., Beebe S., Polania J., Ricaurte J., Cajiao C., Garcia R. \& Rivera M. (2013). Can Tepary Bean be a model for improvement of drought resistance in common bean? African Crop Science Journal , 21(4), $265-281$

Rewald B., Ephrath J.E. \& Rachmilevitch S. (2011). A root is a root is a root? Water uptake rates of Citrus root orders. Plant Cell and Environment, 34(1), 33-42.

Richards R.A. \& Passioura J.B. (1989). A breeding program to reduce the diameter of the major xylem vessel in the seminar roots of wheat and its effect on grain-yield in rain-fed environments. Australian Journal of Agricultural Research, 40(5), 943-950.

Schreiber L. (2010). Transport barriers made of cutin, suberin and associated waxes. Trends in Plant Science, 15(10), 546-553.

Schreiber S.G., Hacke U.G., Hamann A. \& Thomas B.R. (2011). Genetic variation of hydraulic and wood anatomical traits in hybrid poplar and trembling aspen. New Phytologist, 190(1), 150-160.

Singh S.P., Gepts P. \& Debouck D.G. (1991). Races of common bean (Phaseolus vulgaris, Fabaceae). Economic Botany , 45, 379-396.

Smart R.E. \& Bingham G.E. (1974). Rapid estimates of relative water content. Plant Physiology, 53(2), 258260.

Sperry J.S., Donnelly J.R. \& Tyree M.T. (1988). A method for measuring hydraulic conductivity and embolism in xylem. Plant Cell and Environment, 11(1), 35-40.

Sperry J.S. \& Ikeda T. (1997). Xylem cavitation in roots and stems of Douglas-fir and white fir. Tree Physiology, 17, 275-280.

Sperry J.S. \& Saliendra N.Z. (1994). Intra-plant and inter-plant variation in xylem cavitation in Betulaoccidentalis . Plant Cell and Environment, 17(4), 1233-1241. 
Sperry J.S. \& Tyree M.T. (1988). Mechanism of water stress-induced xylem embolism. Plant Physiology, 88(3), 581-587.

Steudle E. (2000). Water uptake by roots: effects of water deficit.Journal of Experimental Botany , 51(350), 1531-1542.

Stiller V., Sperry J.S. \& Lafitte R. (2005). Embolized conduits of rice (Oryza sativa, Poaceae ) refill despite negative xylem pressure.American Journal of Botany, 92(12), 1970-1974.

Strock C.F., de la Riva L.M. \& Lynch J.P. (2018). Reduction in Root Secondary Growth as a Strategy for Phosphorus Acquisition. Plant Physiology , 176(1), 691-703.

Strock C.F., Burridge J., Massas A.S.F., Beaver J., Beebe S., Camilo S.A., Fourie D., Jochua C., Miguek M., Miklas P.N., Mndolwa E., Nchimbi-Msolla S., Polania J., Porch T.G., Rosas J.C., Trapp J.J. \& Lynch J.P. (2019a). Seedling Root Architecture and its Relationship With Seed Yield Across Diverse Environments in Phaseolus vulgaris .Field Crops Research , 237(1), 53-64.

Strock C.F. \& Lynch J.P. (2020). Root Secondary Growth: An Unexplored Component of Soil Resource Acquisition. Annals of Botany ,in press .

Strock C.F., Schneider H.M., Galindo-Castañeda T., Hall B.T., Van Gansbeke B., Mather D.E., Roth M.G., Chilvers M.I., Guo X., Brown K.M. \& Lynch J.P. (2019b). Laser ablation tomography for visualization of root colonization by edaphic organisms. Journal of Experimental Botany, 70(19), 5327-5342.

Thomas C.V. (1983). Physiological and genetics studies of drought resistance in Phaseolus vulgaris L. and P. acutifolius A. Gray. Ph.D. dissertation. University of California, Riverside.

Tyree M.T., Davis S.D. \& Cochard H. (1994). Biophysical perspectives of xylem evolution - Is there a tradeoff of hydraulic efficiency for vulnerability to dysfunction. Iawa Journal, 15(4), 335-360.

Vadez V. (2014). Root hydraulics: The forgotten side of roots in drought adaptation. Field Crops Research, $165,15-24$.

White J.W. \& Laing D.R. (1989). Photoperiod response of flowering in diverse genotypes of common bean (Phaseolus vulgaris ).Field Crops Research , 22(2), 113-128.

White J.W., Rassweiler A., Samhouri J.F., Stier A.C. \& White C. (2014). Ecologists should not use statistical significance tests to interpret simulation model results. Oikos , 123(4), 311-321.

Zhan A., Schneider H. \& Lynch J.P. (2015). Reduced lateral root branching density improves drought tolerance in maize. Plant Physiology, 168(4), 1603-1615.

Zimmerman M.H. (1983). Xylem Structure and the Ascent of Sap. USA: Springer.

Zwieniecki M.A., Thompson M.V. \& Holbrook N.M. (2002). Understanding the hydraulics of porous pipes: Tradeoffs between water uptake and root length utilization. Journal of Plant Growth Regulation, 21(4), 315323.

Tables

Table 1. Allometric analysis comparing shoot biomass to root phenes of tepary bean (P. acutifolius) in the greenhouse at 14, 28, and $42 \mathrm{DAP}$, and in the field at 57 DAP. Root phenes include total cross sectional area $\left(\mathrm{TCSA} ; \mathrm{mm}^{2}\right)$, metaxylem vessel area $\left(\mathrm{XA} ; \mathrm{mm}^{2}\right)$, metaxylem vessel number $(\mathrm{XN})$, mean metaxylem vessel size (MXS; $\mathrm{mm}^{2}$ ), percent stele area (\% Stele), theoretical axial hydraulic conductance (cond.; $\mathrm{kg} \mathrm{m} \mathrm{MPa}{ }^{-1}$ $\mathrm{s}^{-1}$ ), adventitious root number (ARN), basal root number (BRN), basal root whorl number (BRWN), and total root dry mass (R Mass; g). Anatomical data were means from the taproot for each mesocosm/plot. Adjusted coefficient of determination $\left(\mathrm{R}^{2}\right)$, y intercept (Int.), scaling coefficient $(\alpha)$, and P-value $(p)$ for the regression line are shown. Boldface indicates a significant relationship at $\mathrm{P}<0.05$. 


\begin{tabular}{|c|c|c|c|c|c|c|c|c|}
\hline & & $\begin{array}{l}\text { Water } \\
\text { Stress }\end{array}$ & $\begin{array}{l}\text { Water } \\
\text { Stress }\end{array}$ & $\begin{array}{l}\text { Water } \\
\text { Stress }\end{array}$ & $\begin{array}{l}\text { Water } \\
\text { Stress }\end{array}$ & $\begin{array}{l}\text { Well } \\
\text { Watered }\end{array}$ & $\begin{array}{l}\text { Well } \\
\text { Watered }\end{array}$ & $\begin{array}{l}\text { Well } \\
\text { Watered }\end{array}$ \\
\hline & & $\mathrm{R}^{2}$ & Int. & $(\alpha)$ & $\mathrm{P}$ & $\mathrm{R}^{2}$ & Int. & $(\alpha)$ \\
\hline \multirow{10}{*}{$\begin{array}{l}\text { Greenhouse } \\
14 \text { DAP }\end{array}$} & TCSA & & & & & 0.03 & -0.22 & 0.47 \\
\hline & $\mathrm{XA}$ & & & & & 0.35 & 0.57 & 0.58 \\
\hline & $\mathrm{XN}$ & & & & & 0.08 & -1.03 & 0.43 \\
\hline & MXS & & & & & 0.40 & 3.26 & 1.16 \\
\hline & $\%$ Stele & & & & & 0.29 & -2.03 & 1.00 \\
\hline & Cond. & & & & & 0.41 & 1.93 & 0.40 \\
\hline & $\mathrm{ARN}$ & & & & & -0.09 & -0.41 & 0.07 \\
\hline & $\mathrm{BRN}$ & & & & & 0.03 & -0.81 & 0.46 \\
\hline & BRWN & & & & & 0.07 & -0.52 & 0.44 \\
\hline & R. & & & & & 0.07 & -0.05 & 0.45 \\
\hline \multirow{11}{*}{$\begin{array}{l}\text { Greenhouse } \\
28 \text { DAP }\end{array}$} & TCSA & -0.06 & 1.08 & -0.02 & 0.91 & 0.32 & 33.08 & -62.40 \\
\hline & XA & 0.06 & 1.25 & 0.24 & 0.16 & 0.95 & 18.32 & 30.31 \\
\hline & $\mathrm{XN}$ & 0.06 & 1.40 & -0.18 & 0.17 & 0.97 & 36.07 & -18.02 \\
\hline & MXS & 0.52 & 2.34 & 0.49 & $<0.01$ & 0.87 & - & -42.84 \\
\hline & & & & & & & 104.88 & \\
\hline & $\%$ Stele & -0.03 & -3.62 & 2.35 & 0.46 & 1.0 & 113.52 & -56.17 \\
\hline & Cond. & 0.51 & 2.52 & 0.33 & $<0.01$ & 0.97 & 65.61 & 15.63 \\
\hline & $\mathrm{ARN}$ & -0.10 & 1.10 & -0.03 & 0.85 & 0.69 & 29.35 & -43.63 \\
\hline & $\mathrm{BRN}$ & -0.01 & 0.97 & 0.12 & 0.38 & 0.44 & 62.95 & -68.94 \\
\hline & BRWN & -0.05 & 1.06 & 0.04 & 0.74 & 0.32 & -9.12 & 54.22 \\
\hline & $\begin{array}{l}\text { R. } \\
\text { Mass }\end{array}$ & 0.06 & -2.87 & 1.90 & 0.16 & 0.37 & -11.40 & 38.55 \\
\hline \multirow{9}{*}{$\begin{array}{l}\text { Greenhouse } \\
42 \text { DAP }\end{array}$} & TCSA & -0.06 & 1.55 & $<0.01$ & 0.99 & 0.38 & 1.44 & 0.54 \\
\hline & XA & -0.06 & 1.56 & 0.02 & 0.85 & 0.14 & 1.92 & 0.40 \\
\hline & $\mathrm{XN}$ & -0.02 & 1.35 & 0.10 & 0.42 & 0.17 & 0.82 & 0.44 \\
\hline & MXS & -0.01 & 1.13 & -0.16 & 0.37 & -0.06 & 1.72 & -0.02 \\
\hline & Cond. & -0.06 & 1.49 & -0.01 & 0.88 & -0.05 & 2.05 & 0.07 \\
\hline & ARN & 0.04 & 1.50 & 0.09 & 0.24 & -0.07 & 1.80 & -0.06 \\
\hline & $\mathrm{BRN}$ & -0.04 & 1.60 & -0.05 & 0.58 & 0.11 & 2.07 & -0.31 \\
\hline & BRWN & -0.04 & 1.56 & -0.06 & 0.57 & 0.02 & 1.85 & -0.22 \\
\hline & $\begin{array}{l}\text { R. } \\
\text { Mass }\end{array}$ & 0.01 & 1.62 & -0.19 & 0.30 & -0.05 & 1.70 & 0.09 \\
\hline \multirow{8}{*}{$\begin{array}{l}\text { Field } 57 \\
\text { DAP }\end{array}$} & TCSA & 0.06 & 1.76 & 0.37 & 0.14 & 0.07 & 1.75 & 0.48 \\
\hline & $\mathrm{XA}$ & 0.44 & 2.31 & 0.83 & $<0.01$ & 0.40 & 2.22 & 0.58 \\
\hline & $\mathrm{XN}$ & 0.15 & 0.69 & 0.57 & 0.03 & 0.20 & 0.41 & 0.75 \\
\hline & MXS & 0.23 & 5.12 & 1.18 & 0.01 & 0.23 & 3.70 & 0.66 \\
\hline & Cond. & 0.56 & 4.76 & 0.65 & $<0.01$ & 0.34 & 3.29 & 0.31 \\
\hline & $\mathrm{ARN}$ & 0.33 & 1.82 & 0.56 & 0.02 & -0.03 & 2.11 & 0.09 \\
\hline & BRN & 0.48 & 1.30 & 0.90 & $<0.01$ & 0.19 & 1.84 & 0.40 \\
\hline & BRWN & 0.19 & 1.84 & 0.71 & 0.03 & 0.21 & 2.06 & 0.42 \\
\hline
\end{tabular}

Table 2. Allometric analysis comparing shoot biomass to root phenes of common bean (P. vulgaris ) in the 
greenhouse at 14, 28, and $42 \mathrm{DAP}$, and in the field at 57 DAP. Root phenes include total cross sectional area $\left(\mathrm{TCSA} ; \mathrm{mm}^{2}\right)$, metaxylem vessel area $\left(\mathrm{XA} ; \mathrm{mm}^{2}\right)$, metaxylem vessel number $(\mathrm{XN})$, mean metaxylem vessel size (MXS; $\mathrm{mm}^{2}$ ), percent stele area (\% Stele), theoretical axial hydraulic conductance (cond.; $\mathrm{kg} \mathrm{m} \mathrm{MPa}^{-1}$ $\mathrm{s}^{-1}$ ), adventitious root number (ARN), basal root number (BRN), basal root whorl number (BRWN), and total root dry mass (R Mass; g). Anatomical data were means from the taproot for each mesocosm/plot. Adjusted coefficient of determination $\left(\mathrm{R}^{2}\right)$, y intercept (Int.), scaling coefficient $(\alpha)$, and P-value $(p)$ for the regression line are shown. Boldface indicates a significant relationship at $\mathrm{P}<0.05$.

\begin{tabular}{|c|c|c|c|c|c|c|c|c|}
\hline & & $\begin{array}{l}\text { Water } \\
\text { Stress }\end{array}$ & $\begin{array}{l}\text { Water } \\
\text { Stress }\end{array}$ & $\begin{array}{l}\text { Water } \\
\text { Stress }\end{array}$ & $\begin{array}{l}\text { Water } \\
\text { Stress }\end{array}$ & $\begin{array}{l}\text { Well } \\
\text { Watered }\end{array}$ & $\begin{array}{l}\text { Well } \\
\text { Watered }\end{array}$ & $\begin{array}{l}\text { Well } \\
\text { Watered }\end{array}$ \\
\hline & & $\mathrm{R}^{2}$ & Int. & $(\alpha)$ & $\mathrm{P}$ & $\mathrm{R}^{2}$ & Int. & $(\alpha)$ \\
\hline \multirow{10}{*}{$\begin{array}{l}\text { Greenhouse } \\
14 \text { DAP }\end{array}$} & TCSA & & & & & 0.11 & 0.24 & 0.54 \\
\hline & XA & & & & & 0.08 & 0.55 & 0.28 \\
\hline & $\mathrm{XN}$ & & & & & -0.03 & -0.02 & 0.09 \\
\hline & MXS & & & & & $<0.01$ & 0.67 & 0.18 \\
\hline & $\%$ Stele & & & & & $<0.01$ & -0.39 & 0.31 \\
\hline & Cond. & & & & & 0.11 & 1.02 & 0.16 \\
\hline & $\mathrm{ARN}$ & & & & & -0.02 & 0.14 & -0.07 \\
\hline & BRN & & & & & -0.05 & 0.09 & 0.03 \\
\hline & BRWN & & & & & -0.01 & 0.25 & -0.29 \\
\hline & $\begin{array}{l}\text { R. } \\
\text { Mass }\end{array}$ & & & & & 0.25 & 0.18 & 0.45 \\
\hline \multirow{10}{*}{$\begin{array}{l}\text { Greenhouse } \\
28 \text { DAP }\end{array}$} & TCSA & 0.02 & 0.98 & 0.33 & 0.28 & 0.38 & 1.10 & 0.46 \\
\hline & $\mathrm{XA}$ & 0.10 & 1.35 & 0.34 & 0.11 & 0.23 & 1.58 & 0.39 \\
\hline & $\mathrm{XN}$ & 0.11 & 2.06 & -0.55 & 0.10 & 0.11 & 0.57 & 0.37 \\
\hline & MXA & 0.18 & 1.89 & 0.31 & 0.05 & $<-0.01$ & 1.80 & 0.21 \\
\hline & $\%$ Stele & $<0.01$ & 3.58 & -1.27 & 0.32 & -0.02 & 0.37 & 0.45 \\
\hline & Cond. & 0.15 & 1.97 & 0.19 & 0.06 & 0.17 & 2.28 & 0.22 \\
\hline & $\mathrm{ARN}$ & -0.04 & 1.16 & -0.13 & 0.61 & -0.02 & 1.11 & 0.15 \\
\hline & BRN & -0.05 & 1.27 & -0.23 & 0.65 & -0.07 & 1.24 & 0.017 \\
\hline & BRWN & $<0.01$ & 0.92 & 0.33 & 0.34 & -0.07 & 1.23 & 0.055 \\
\hline & $\begin{array}{l}\text { R. } \\
\text { Mass }\end{array}$ & 0.11 & 0.69 & 0.42 & 0.10 & 0.53 & 0.92 & 0.43 \\
\hline \multirow{9}{*}{$\begin{array}{l}\text { Greenhouse } \\
42 \text { DAP }\end{array}$} & TCSA & -0.04 & 1.48 & -0.05 & 0.70 & 0.08 & 1.64 & 0.19 \\
\hline & XA & -0.04 & 1.49 & 0.03 & 0.81 & 0.03 & 1.82 & 0.14 \\
\hline & $\mathrm{XN}$ & -0.04 & 1.37 & 0.05 & 0.79 & 0.15 & 1.14 & 0.31 \\
\hline & MXA & -0.05 & 1.51 & 0.02 & 0.90 & -0.05 & 1.51 & -0.09 \\
\hline & Cond. & -0.03 & 1.63 & 0.03 & 0.60 & -0.04 & 1.97 & 0.05 \\
\hline & $\mathrm{ARN}$ & -0.05 & 1.46 & 0.01 & 0.96 & 0.34 & 1.39 & 0.39 \\
\hline & BRN & -0.04 & 1.37 & 0.09 & 0.82 & -0.04 & 1.53 & 0.20 \\
\hline & BRWN & -0.05 & 1.48 & -0.03 & 0.93 & -0.05 & 1.67 & 0.16 \\
\hline & $\begin{array}{l}\text { R. } \\
\text { Mass }\end{array}$ & 0.17 & 1.71 & -0.31 & 0.03 & 0.49 & 1.15 & 0.56 \\
\hline \multirow{4}{*}{$\begin{array}{l}\text { Field } 57 \\
\text { DAP }\end{array}$} & TCSA & 0.10 & 2.16 & -0.44 & 0.08 & 0.09 & 2.10 & 0.14 \\
\hline & XA & 0.06 & 1.73 & -0.28 & 0.13 & 0.05 & 2.24 & 0.10 \\
\hline & XN & 0.12 & 2.78 & -0.40 & 0.06 & -0.02 & 2.02 & 0.08 \\
\hline & MXA & -0.04 & 1.97 & 0.03 & 0.92 & 0.02 & 2.51 & 0.12 \\
\hline
\end{tabular}




\begin{tabular}{|c|c|c|c|c|c|c|c|}
\hline & $\begin{array}{l}\text { Water } \\
\text { Stress }\end{array}$ & $\begin{array}{l}\text { Water } \\
\text { Stress }\end{array}$ & $\begin{array}{l}\text { Water } \\
\text { Stress }\end{array}$ & $\begin{array}{l}\text { Water } \\
\text { Stress }\end{array}$ & $\begin{array}{l}\text { Well } \\
\text { Watered }\end{array}$ & $\begin{array}{l}\text { Well } \\
\text { Watered }\end{array}$ & $\begin{array}{l}\text { Well } \\
\text { Watered }\end{array}$ \\
\hline Cond. & 0.02 & 1.25 & -0.14 & 0.26 & 0.03 & 2.46 & 0.06 \\
\hline ARN & 0.09 & 1.75 & 0.27 & 0.09 & -0.05 & 2.20 & 0.01 \\
\hline BRN & 0.01 & 1.33 & 0.59 & 0.28 & 0.02 & 2.45 & -0.27 \\
\hline BRWN & -0.03 & 1.79 & 0.27 & 0.61 & -0.04 & 2.22 & -0.05 \\
\hline
\end{tabular}

\section{Figure Legends}

Figure 1. Relationship between axial conductance measured across $5 \mathrm{~cm}$ taproot segments and the theoretical axial conductance calculated across the same root segment for roots of greenhouse-grown plants harvested at 14 DAP (A), 28 DAP (B), and 42 DAP (C). Red lines indicate a significant correlation at a confidence level of $\alpha$ [?] 0.05 using Pearson's product-moment correlation analysis. $\mathrm{n}_{14 \mathrm{DAP}}=45, \mathrm{n}_{28 \mathrm{DAP}}=$ $73, \mathrm{n}_{42 \mathrm{DAP}}=79$

Figure 2. Theoretical axial conductance $\left(\mathrm{kg} \mathrm{m} \mathrm{MPa} \mathrm{m}^{-1} \mathrm{~s}^{-1}\right)$, metaxylem number, mean metaxylem size $\left(\mathrm{mm}^{2}\right)$, and total cross sectional area (TCSA; $\mathrm{mm}^{2}$ ) of the taproot from P. acutifoliusand P. vulgaris accessions at 9, 14, 28, and 42 DAP grown under water stress in the greenhouse. Values shown are Mean $\pm \mathrm{SE}$. Comparisons are made across species and phenotypes within each time point. ${ }^{*}$ indicates significant species differences and + indicates significant phenotypic differences within species at $\alpha[?] 0.05$. Insets magnify 9 and 14 DAP timepoints.

Figure 3. (A) Carbon concentration (\%), hydrogen concentration (\%), and carbon:hydrogen ratio of roots grown under water stress in the field at 57 DAP. Values shown are Mean \pm SE. Comparisons are made across species and phenotypic groups. $\mathrm{n}=48$. (B) High-conductance genotypes in both $P$. acutifolius and $P$. vulgaris were observed to have a bark-like, hard, woody periderm, while low-conductance genotypes displayed a smooth, thicker, corky periderm. (C) Three-dimensional reconstruction of high and low conductance root segments showing contrast in metaxylem vessel morphology.

Figure 4. Dry shoot mass $\left(\mathrm{g}\right.$ plant $\left.{ }^{-1}\right)$, root mass $\left(\mathrm{g}\right.$ plant $\left.{ }^{-1}\right)$, and root:shoot mass ratio for $P$. acutifolius and $P$. vulgaris accessions with contrasting conductance grown in mesocosms under water stress at 14,28 , and 42 DAP. Values shown are Mean \pm SE. Comparisons are made across species and phenotypes within each time point. ${ }^{*}$ indicates significant species differences and + indicates significant phenotypic differences within species at $\alpha[?] 0.05$. Insets magnify 14 and 28 DAP timepoints.

Figure 5. OpenSimRoot results showing the root length distribution of P. vulgaris and P. acutifolius root architectures at 40 days of growth (A, B). The model was parameterized from measures of root architecture of each species in the field. Nitrogen availability in the model was limited and stratified by depth as a proxy for water availability, and root growth was confined to a $0.6 \times 0.6 \times 1.5 \mathrm{~m}$ deep soil volume. Any roots that intersected the boundary of the soil environment were mirrored back to maintain root length similar to that of field conditions.

Figure 6. Correlations between the reduction in shoot mass under water stress (\%) and total metaxylem vessel area $\left(\mathrm{mm}^{2}\right)(\mathrm{A}, \mathrm{B})$, metaxylem vessel number $(\mathrm{C}, \mathrm{D})$, and theoretical taproot conductance $(\mathrm{kg} \mathrm{m}$ $\left.\mathrm{MPa}^{-1} \mathrm{~S}^{-1}\right)(\mathrm{E}, \mathrm{F})$ for $P$. acutifolius and $P$. vulgaris in the field at 57 DAP. Red lines indicate significant correlations at the confidence level of $\alpha[?] 0.05$, and solid black lines indicate significant correlations at $\alpha$ [?]0.1 using Pearson's product-moment correlation analysis. $\mathrm{n}=24$

Figure 7. (A-C) Net transpiration rate $\left(\mathrm{mmol} \mathrm{m}^{-2} \mathrm{~s}^{-1}\right)$ for $P$. acutifoliusand $P$. vulgaris accessions with contrasting conductance in the greenhouse under water stress at 13 (A), 27 (B), and 41 DAP (C). Values shown are Mean $\pm \mathrm{SE}$. Comparisons are made across species and phenotypic groups within each timepoint. * indicates significant species differences and + indicates significant phenotypic differences at $\alpha$ [?]0.05. (D) Leaf RWC (\%) of P. acutifolius and P. vulgarisgenotypes under well-watered and water stress conditions at 
42 DAP in mesocosms (D). Values shown are Mean \pm SE. Comparisons in panel 'D' are made across species, phenotypic groups, and irrigation treatments.

Figure 8. Transpired water (L), transpired $\mathrm{H}_{2} \mathrm{O}$ leaf area ${ }^{-1}\left(\mathrm{~L} \mathrm{~cm}^{-2}\right)$, transpired $\mathrm{H}_{2} \mathrm{O}$ shoot mass ${ }^{-1}\left(\mathrm{~L} \mathrm{~g}^{-1}\right)$, transpired $\mathrm{H}_{2} \mathrm{O}$ root mass ${ }^{-1}\left(\mathrm{~L} \mathrm{~g}^{-1}\right)$ for $P$. acutifolius and $P$. vulgaris accessions with contrasting conductance grown under water stress in the greenhouse at $42 \mathrm{DAP}$. Values shown are Mean $\pm \mathrm{SE}$. Comparisons are made across species and phenotypes within each time point.

Figure 9. Transpiration rate $\left(\mathrm{mmol} \mathrm{m}^{-2} \mathrm{~s}^{-1}\right)(\mathrm{A})$, and net transpiration $\left(\mathrm{mol} \mathrm{plant} \mathrm{t}^{-1} \mathrm{~s}^{-1}\right)(\mathrm{B})$ for P. acutifolius and $P$. vulgaris accessions with contrasting conductance in the field under water stress at 64 DAP. Values shown are Mean $\pm \mathrm{SE}$. Comparisons are made across species and phenotypic groups within each time point. * indicates significant species differences and + indicates significant phenotypic differences within species at $\alpha[?] 0.05$. (C) Leaf RWC (\%) of P. acutifolius and P. vulgarisgenotypes under well-watered and water stressed conditions at $57 \mathrm{DAP}$ in the field. Values shown are Mean \pm SE. Comparisons are made across species, phenotypic groups, and irrigation treatments.

\section{Supporting Information}

Supplementary Data S1. OpenSimRoot uses a hierarchical input file which is summarized below. The hierarchy gives the parameters in context. For example, 'specific leaf area' belongs to the shoot of a specific plant. In OpenSimRoot, parameters can be a single value, a value drawn from a distribution (random), or the result of an interpolation table. For constants we give the value, for distributions the distribution parameters, and for tables, a list of space separated values e.g. x1, y1, x2, y2 .. xn, yn. These parameters are based on empirical data from our own measurements or from the literature.

Supplemental Figure S1. Theoretical conductance $\left(\mathrm{kg} \mathrm{m} \mathrm{MPa}^{-1} \mathrm{~s}^{-1}\right)$, metaxylem number, mean metaxylem size $\left(\mathrm{mm}^{2}\right)$, and total cross sectional area $\left(\mathrm{mm}^{2}\right)$ of P. vulgaris (A, B) and P. acutifolius (C, D) accessions at the Apache Root Biology Center, Cochise County, Arizona, USA $\left(32.033896^{\circ} \mathrm{N},-109.692821^{\circ} \mathrm{W}\right)$ in 2015 (A, C) and 2016 (B), and at the University of Puerto Rico Agricultural Experimental Station, Juana Diaz, Puerto Rico $\left(18.031277^{\circ} \mathrm{N},-66.529612^{\circ} \mathrm{W}\right)$ in 2016 (D). Values shown are Mean $\pm \mathrm{SE}$. Comparisons for each variable are made across phenotypic groups.

Supplemental Figure S2. The taproot anatomy of low and high-conductance genotypes in P. acutifolius (A) and P. vulgaris (B) under water stress (WS) and well-watered (WW) conditions in the field at 57 DAP.

Supplemental Figure S3. Rainfall and irrigation on well-watered field (in) (A). Soil moisture content (\%) in the water stressed and well-watered treatments determined from TDR probes placed at $15 \mathrm{~cm}$ and $30 \mathrm{~cm}$ depth from the soil surface (B). Values shown are Mean \pm SE.

Supplemental Figure S4. A comparison of taproot anatomy between high and low-conductance genotypes of $P$. acutifolius (A) and $P$. vulgaris (B) under water stress (WS) and well watered (WW) conditions in mesocosms at 14, 28, and 42 DAP. All cross sections within each panel are at the same scale. Bars $=0.5 \mathrm{~mm}$

Supplemental Figure S5. Theoretical taproot conductance $\left(\mathrm{kg} \mathrm{m} \mathrm{MPa}{ }^{-1} \mathrm{~s}^{-1}\right)$, metaxylem number, mean metaxylem size $\left(\mathrm{mm}^{2}\right)$, and total cross-sectional area $\left(\mathrm{mm}^{2}\right)$ of $P$. acutifolius and $P$. vulgarisaccessions with contrasting conductance phenotypes in the field at 57 DAP. Values shown are Mean \pm SE. Comparisons are made across species and phenotypic groups. (C) Gravimetric soil moisture content (\%) across all depths of mesocosms planted with $P$. acutifolius and $P$. vulgaris after 16 days without irrigation. Lines represent the mean value at each depth while the shaded region shows \pm SE. Welch's Two Sample T-test indicated that $P$. acutifolius had extracted more water from $70-110+\mathrm{cm}$ depth than $P$. vulgaris $(\mathrm{T}=-3.38 ; \mathrm{p}=0.002)$.

Supplemental Figure S6. Leaf area $\left(\mathrm{m}^{2}\right.$ plant $\left.{ }^{-1}\right)$ and leaf number for $P$. acutifolius and $P$. vulgaris accessions with contrasting conductance grown in the greenhouse under water stress at 14, 28, and 42 DAP. Values shown are Mean \pm SE. Comparisons are made across species and phenotypes within each time point. * indicates significant species differences and + indicates significant phenotypic differences within species at $\alpha[?] 0.05$. Insets magnify 14 and 28 DAP timepoints. 
Supplemental Figure S7. Number of basal root whorls, basal roots, and adventitious roots of P. acutifolius and P. vulgaris accessions with contrasting conductance grown in the greenhouse under water stress at 14, 28 , and 42 DAP. Values shown are Mean \pm SE. Comparisons are made across species and phenotypes within each time point. ${ }^{*}$ indicates significant species differences and + indicates significant phenotypic differences within species at $\alpha[?] 0.05$.

Supplemental Figure S8. (A-D) Basal root growth angle (BRGA) (degrees from soil surface) (A), basal root whorl number (BRWN) (B), basal root number (BRN) (C), and adventitious root number (ARN) (D) of $P$. acutifolius and P. vulgaris in the field. Values shown are Mean \pm SE. (E) Excavated root crowns of $P$. acutifolius and $P$. vulgaris from the field at 57 DAP showing differences in architectural phenes related to root depth. (F) $\mathrm{D}_{75}$ (depth at which $75 \%$ of the total root length exists in $60 \mathrm{~cm}$ soil core) of $P$. acutifolius and $P$. vulgaris under water stress in the field at 58 DAP. ${ }^{*}$ indicates significance at $\alpha[?] 0.1$

Supplemental Figure S9. Total root length $(\mathrm{cm})$, fine root length $(<0.12 \mathrm{~mm}$ diameter $)(\mathrm{cm})$, and specific root length $(\mathrm{m} / \mathrm{g})$ by depth for $P$. acutifolius and $P$. vulgaris under water stress at 34 DAP. Values shown are Mean $\pm \mathrm{SE} . *$ indicates significant species differences at each depth.

Supplemental Figure S10. Relationship between gravimetric soil water content and the length of fine roots $(<0.12 \mathrm{~mm}$ diameter) across all depths of mesocosms in both $P$. acutifolius and $P$. vulgaris after 16 days without irrigation. Red line indicates a significant correlation at a confidence level of $\alpha[?] 0.05$.

Supplemental Figure S11. Dry shoot mass (g), leaf area plant ${ }^{-1}\left(\mathrm{~m}^{2}\right)$, and specific leaf mass $\left(\mathrm{g} \mathrm{cm}^{-2}\right)$ of $P$. acutifolius and $P$. vulgaris accessions with contrasting conductance in the field at 57 DAP. Values shown are Mean \pm SE. Comparisons are made across species and phenotypic groups.

Supplemental Figure S12. Violin plots showing median, interquartile range, 95\% confidence intervals, and frequency of grain yield for P. acutifolius $\left(\mathrm{n}_{\text {acutifolius }}=96\right.$ genotypes $)$ and $P$. vulgaris $\left(\mathrm{n}_{\text {vulgaris }}=112\right.$ genotypes) diversity panels under drought stress (A) and well-watered conditions (B) grown at the Apache Root Biology Center, Cochise County, Arizona, USA (32.033896 $\left.\mathrm{N},-109.692821^{\circ} \mathrm{W}\right)$. Letters within each graph denote significant differences as determined by Welch's Two Sample T-test at a confidence level of $\alpha[?] 0.05$.

Supplemental Figure S13. Yield $\left(\mathrm{kg} \mathrm{ha}^{-1}\right)$, pod number plant ${ }^{-1}$, and pod length $(\mathrm{cm})$ of P. acutifolius and $P$. vulgaris accessions with contrasting conductance in the field. Values shown are Mean $\pm \mathrm{SE}$. Comparisons are made across species and phenotypic groups.

Supplemental Figure S14. (A) Leaf imprints showing stomatal density and size on leaves of $P$. acutifolius and $P$. vulgaris . While no species differences in stomatal density were observed, P. acutifolius had $17 \%$ larger stomata than $P$. vulgaris . (B) Stomatal length of $P$. acutifolius and $P$. vulgaris leaves under water stress and well-watered conditions in the field. Values shown are Mean \pm SE. Comparisons are made across species, phenotypic groups, and irrigation treatments.

Supplemental Figure S15. Correlations between leaf RWC (\%) and total metaxylem area $\left(\mathrm{mm}^{2}\right)(\mathrm{A}$, B), metaxylem number (C, D), total cross sectional area (TCSA; $\mathrm{mm}^{2}$ ) (E, F), and theoretical taproot conductance $\left(\mathrm{kg} \mathrm{m} \mathrm{MPa} \mathrm{m}^{-1}\right)(\mathrm{G}, \mathrm{H})$ for $P$. acutifolius and $P$. vulgaris in the field. Red lines indicate significant correlations at the confidence level of $\alpha[?] 0.05$, solid black lines indicate significant correlations at $\alpha[?] 0.1$ using Pearson's product-moment correlation analysis. 


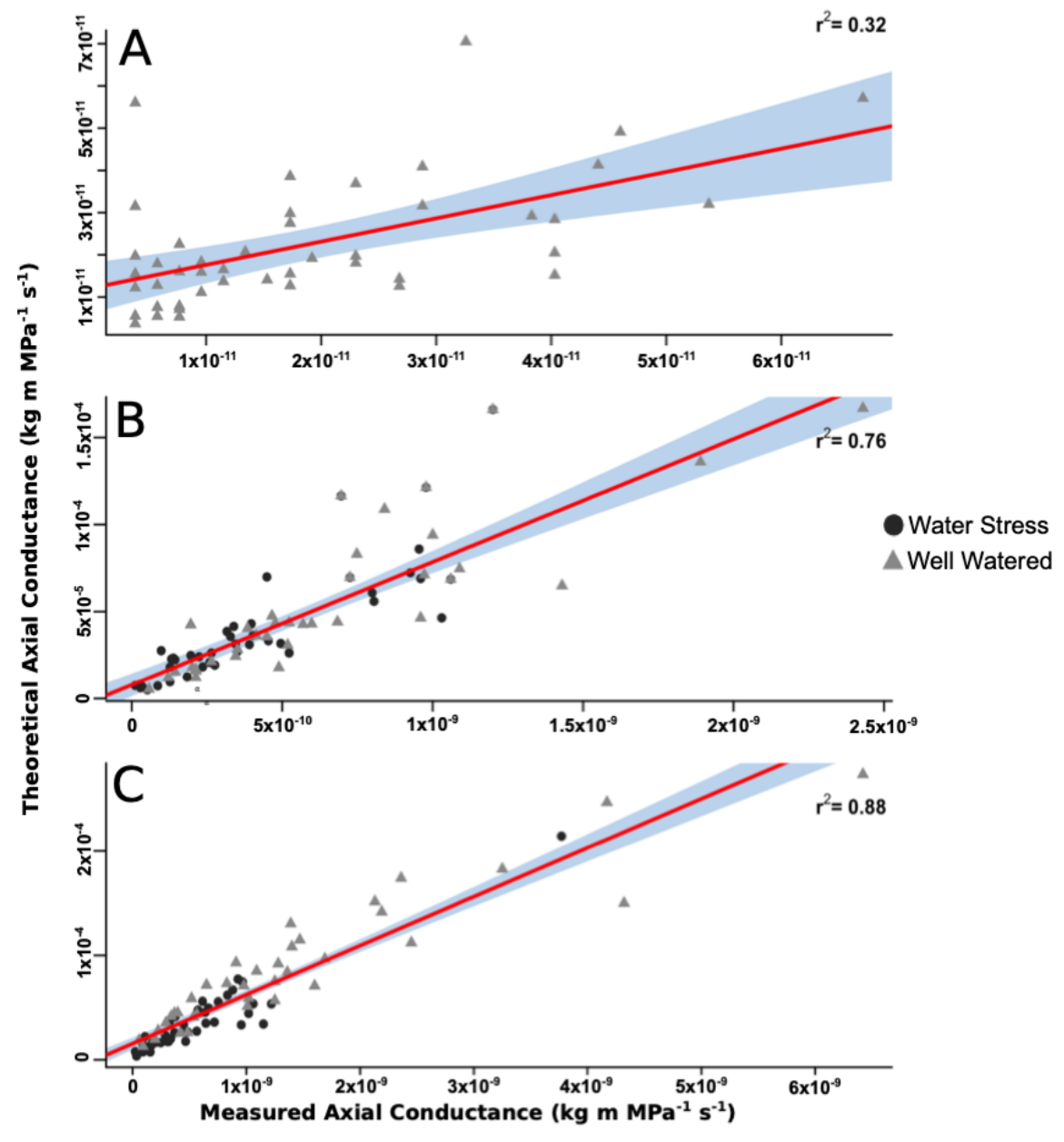




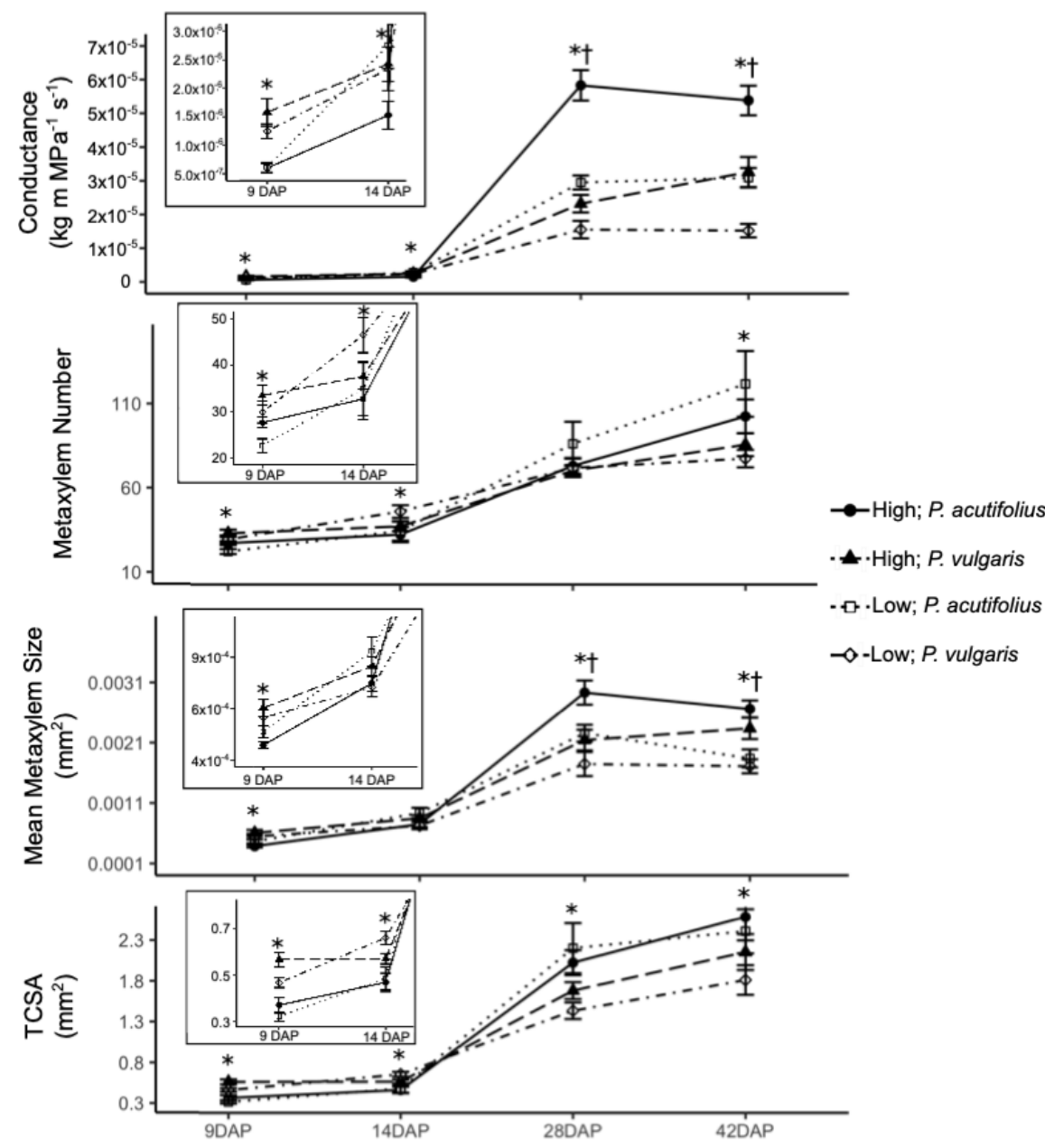



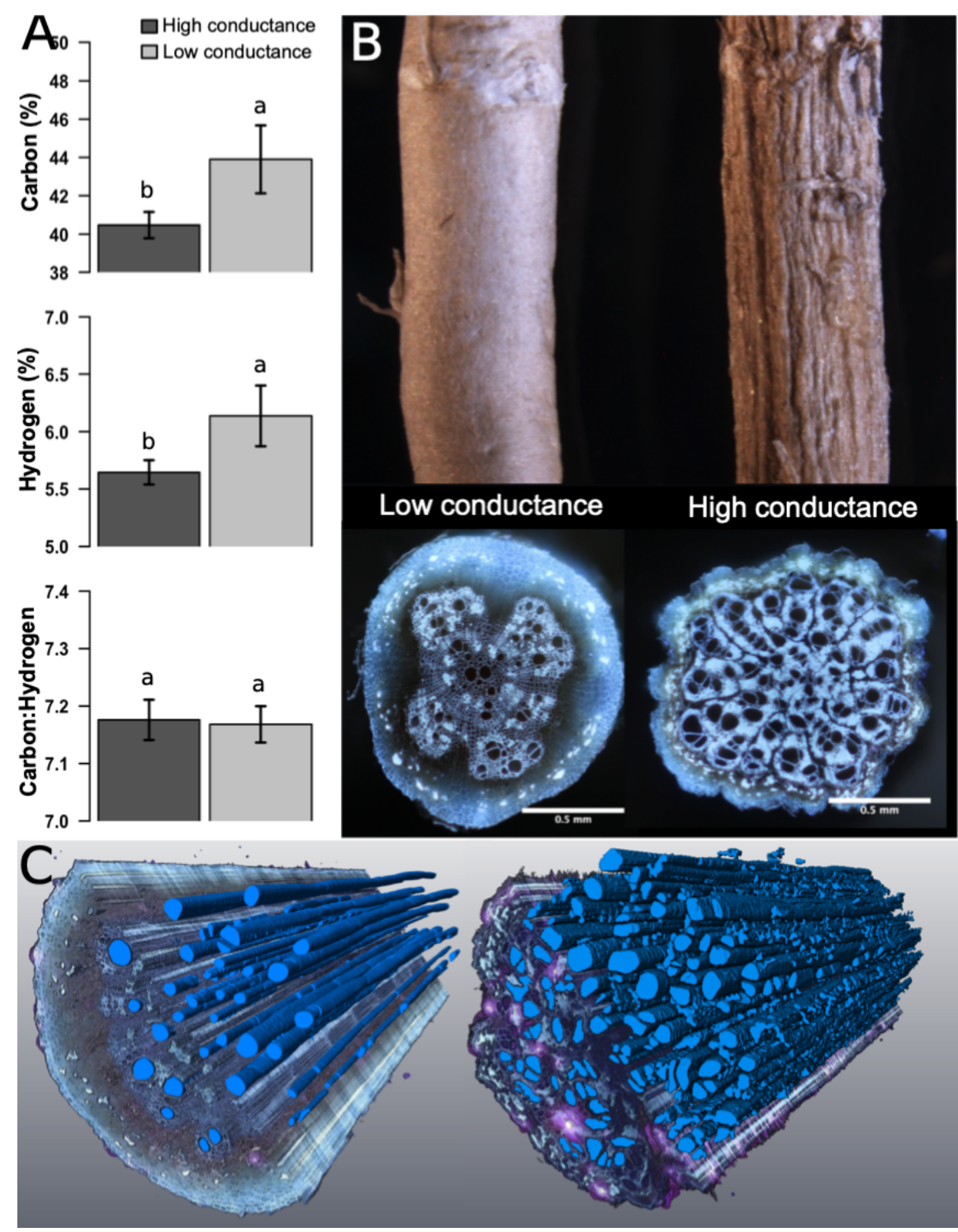

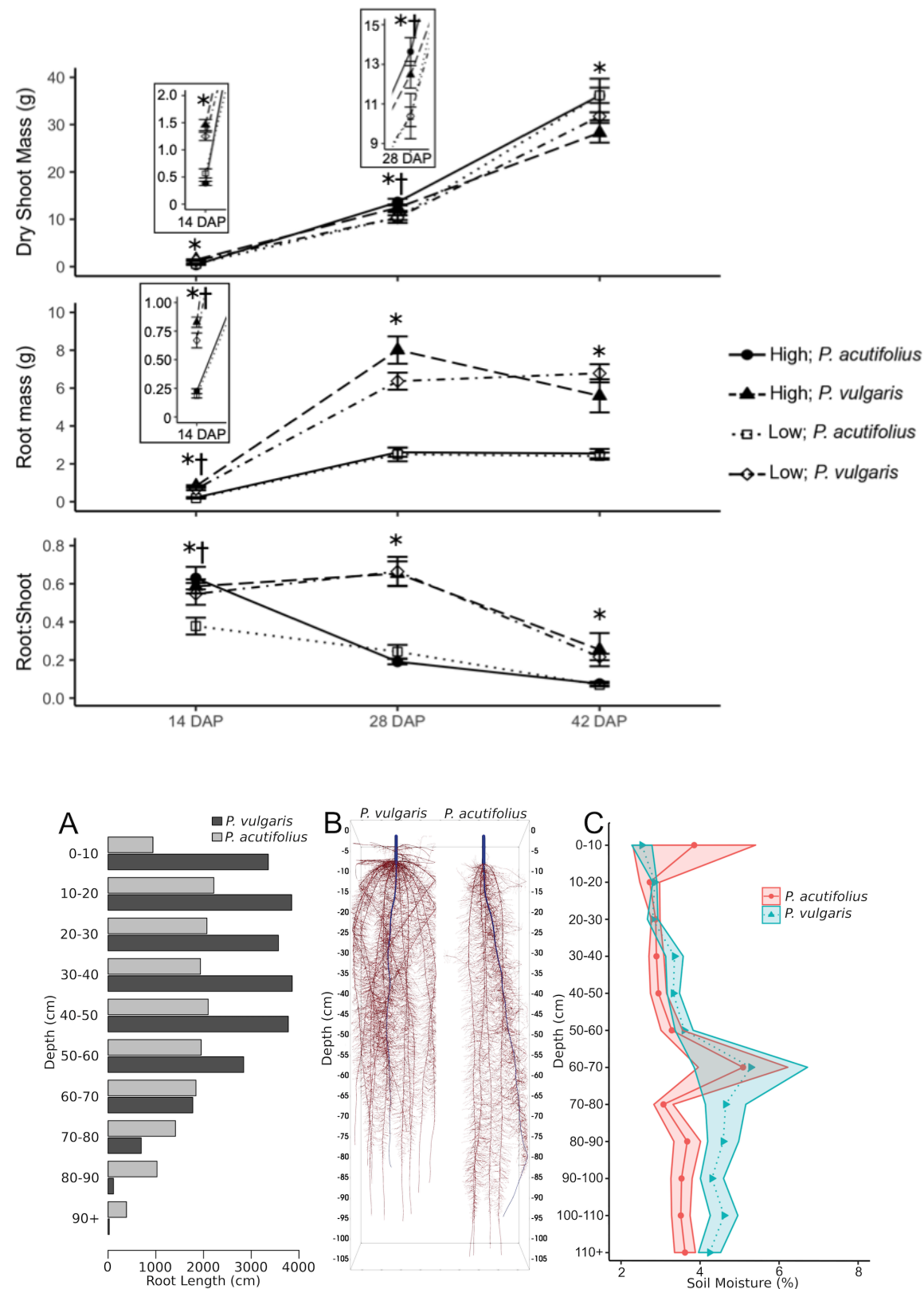

Figure 5.OpenSimRoot results showing the root length distribution of $P$. vulgaris and $P$. acutifolius root architectures at 40 days of growth (A, B). The model was parameterized from measures of root architecture of each species in the field. Nitrogen availability in the model was limited and stratified by depth as a proxy for water availability and root growth was confined to a $0.6 \times 0.6 \times 1.5 \mathrm{~m}$ deep soil volume. Any roots that intersected the boundary of the soil environment were mirrored back to maintain root length similar to that of field conditions. (C) Gravimetric soil moisture content (\%) across all depths of mesocosms planted with $P$. acutifolius and $P$. vulgaris after 16 days without irrigation. Lines represented the mean value at each depth while the shaded region shows $\pm \mathrm{SE}$. Welch's Two Sample T-test indicated that $P$. acutifolius had extracted more water from $70-110+\mathrm{cm}$ depth than $P$. vulgaris $(T=-3.38 ; p=0.002)$. 

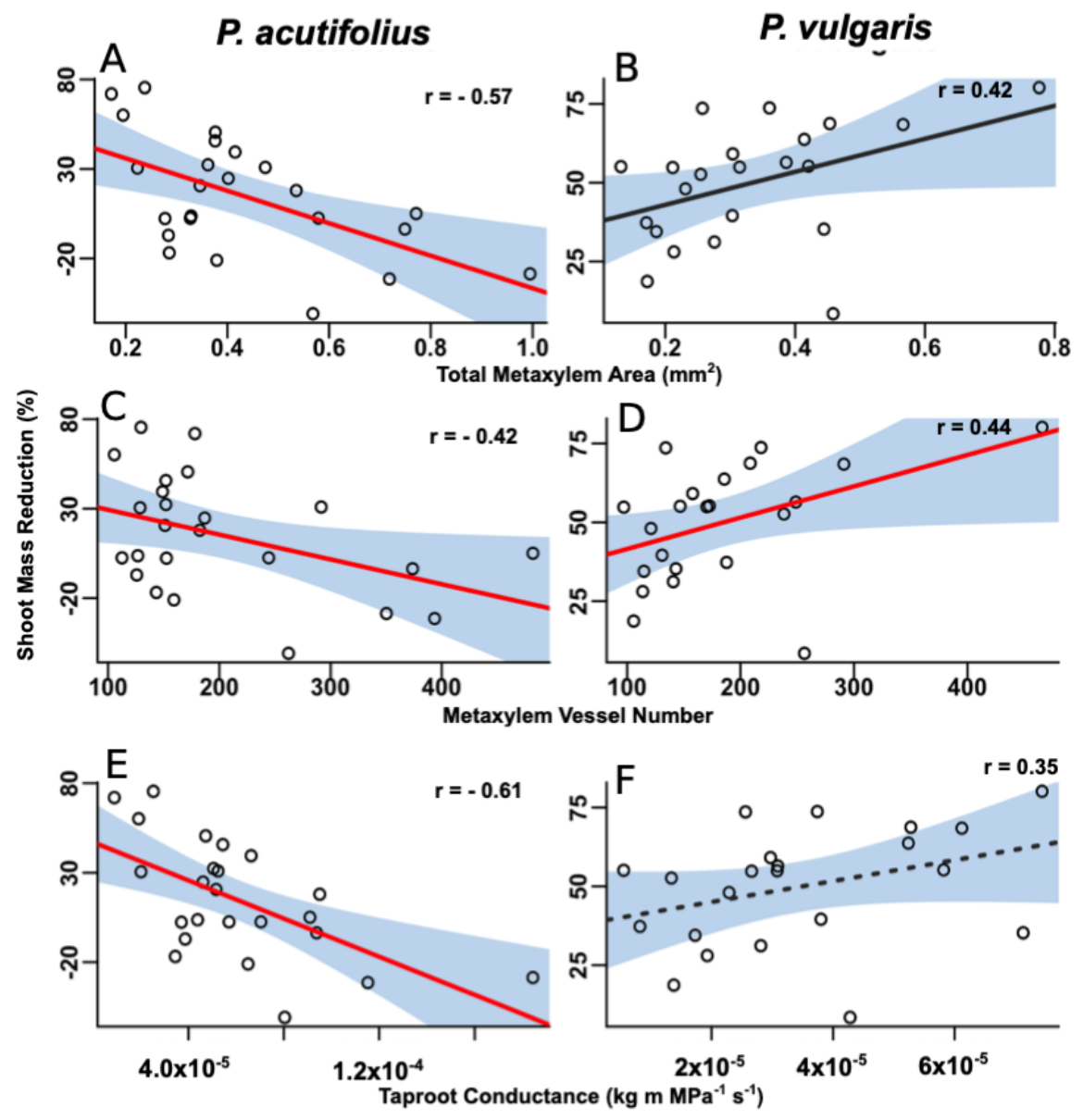


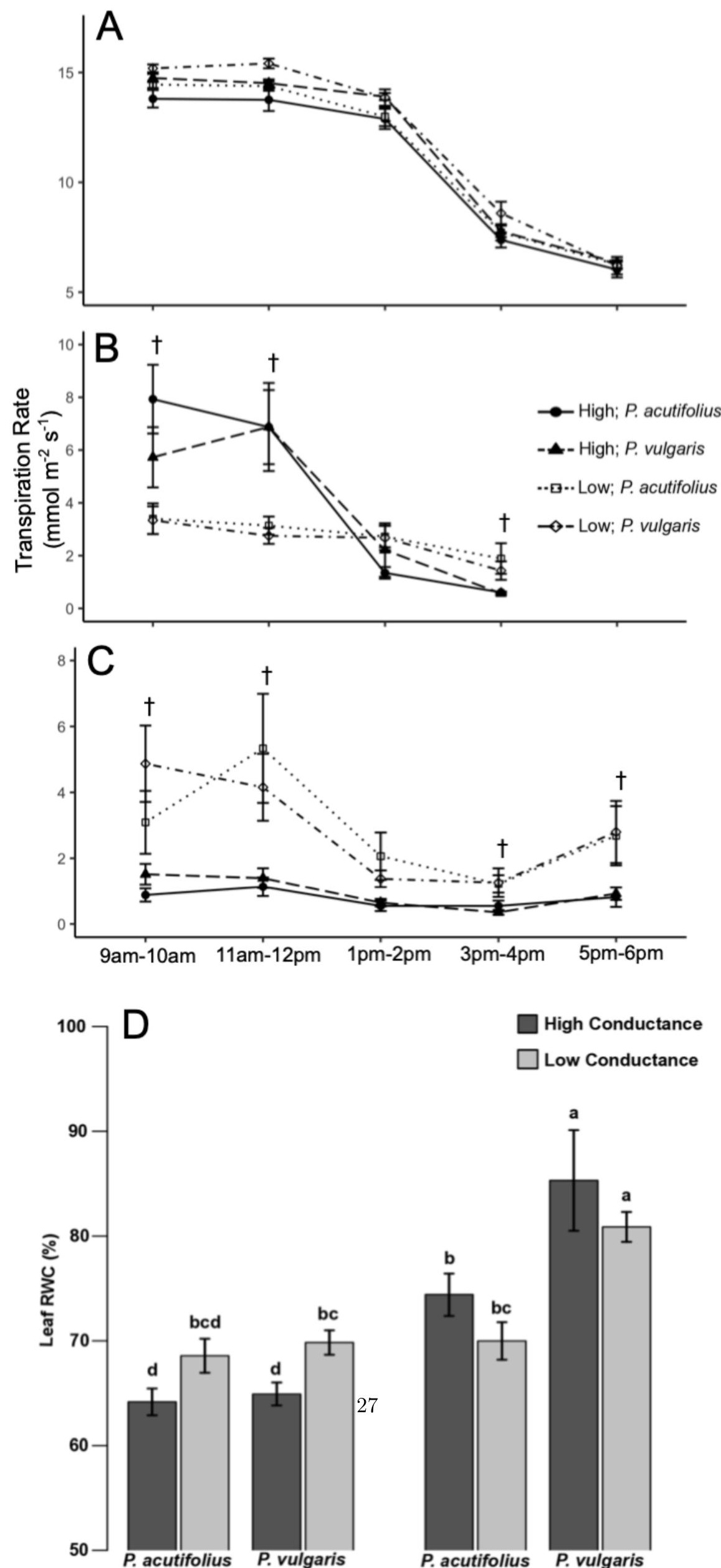



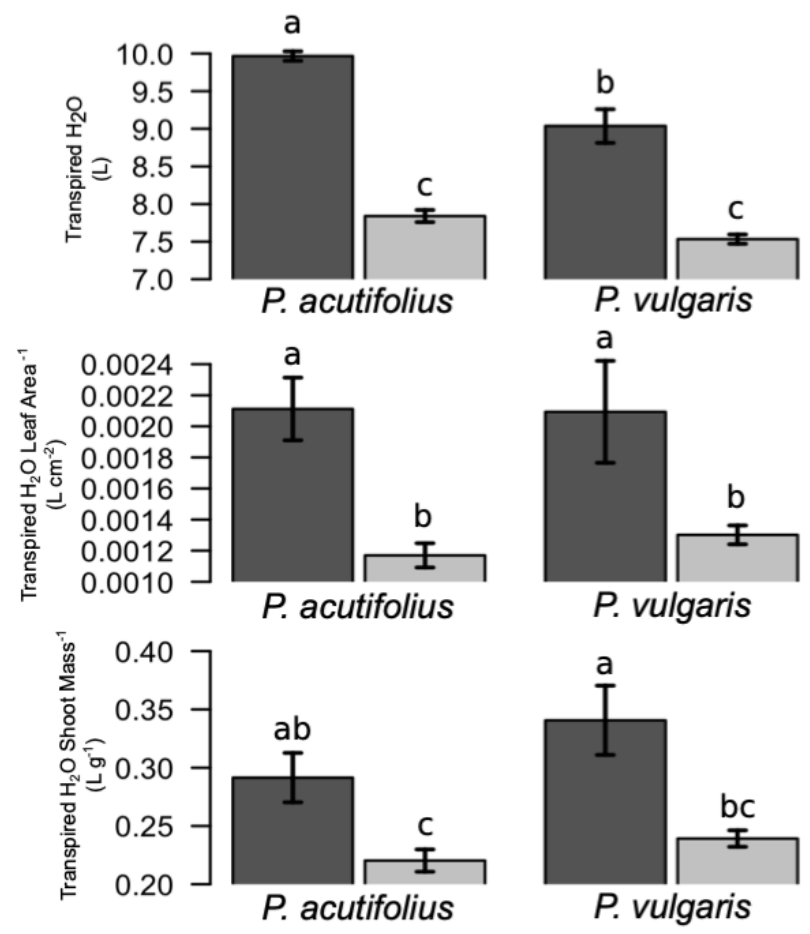

High Conductance

$\square$ Low Conductance
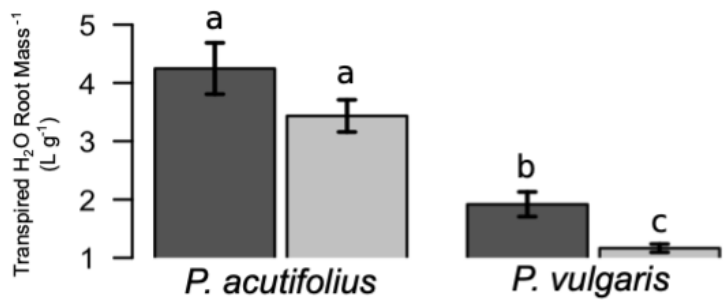

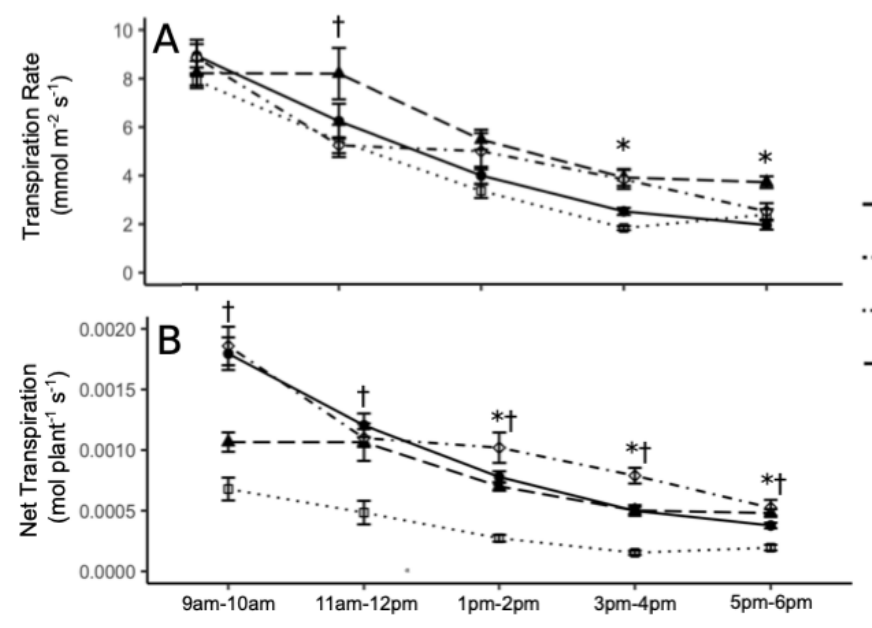

-High; P. acutifolius

-.High; P. vulgaris

- -..Low; P. acutifolius

$\multimap$-Low; P. vulgaris

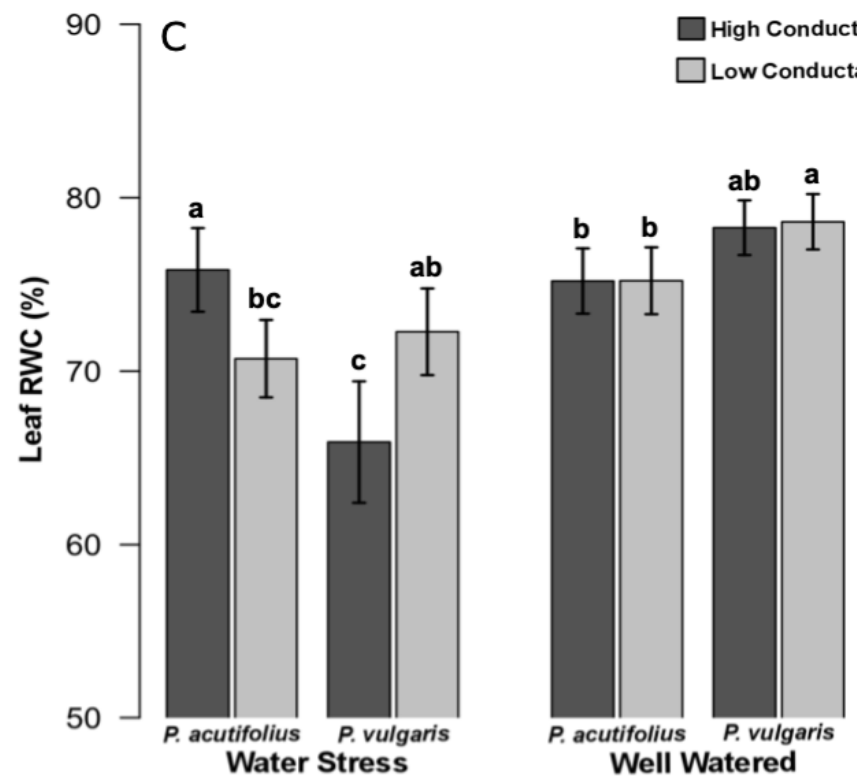

